Review

\title{
Regulation and Metabolic Significance of De Novo Lipogenesis in Adipose Tissues
}

\author{
Ziyi Song, Alus M. Xiaoli and Fajun Yang *
}

Departments of Medicine and Developmental and Molecular Biology, Albert Einstein College of Medicine, Bronx, NY 10461, USA; ziyi.song@einstein.yu.edu (Z.S.); alus.xiaoli@einstein.yu.edu (A.M.X.)

* Correspondence: fajun.yang@einstein.yu.edu; Tel.: +1-(718)-678-1142; Fax: +1-(718)-678-1020

Received: 29 August 2018; Accepted: 21 September 2018; Published: 29 September 2018

\begin{abstract}
De novo lipogenesis (DNL) is a complex and highly regulated process in which carbohydrates from circulation are converted into fatty acids that are then used for synthesizing either triglycerides or other lipid molecules. Dysregulation of DNL contributes to human diseases such as obesity, type 2 diabetes, and cardiovascular diseases. Thus, the lipogenic pathway may provide a new therapeutic opportunity for combating various pathological conditions that are associated with dysregulated lipid metabolism. Hepatic DNL has been well documented, but lipogenesis in adipocytes and its contribution to energy homeostasis and insulin sensitivity are less studied. Recent reports have gained significant insights into the signaling pathways that regulate lipogenic transcription factors and the role of DNL in adipose tissues. In this review, we will update the current knowledge of DNL in white and brown adipose tissues with the focus on transcriptional, post-translational, and central regulation of DNL. We will also summarize the recent findings of adipocyte DNL as a source of some signaling molecules that critically regulate energy metabolism.
\end{abstract}

Keywords: adipocyte; de novo lipogenesis; transcription; post-translation; central regulation; ChREBP; SREBP; LXR; FASN; obesity; insulin resistance; thermogenesis

\section{Introduction}

Adipose tissues (AT), particularly white adipose tissues (WAT), are the major organ for energy storage [1]. WATs store extra energy from diets in the form of triglycerides (TG) or fat, which can be mobilized to meet energy demand in states of fasting or exercise. Meanwhile, ATs are also important endocrine organs. They secrete various adipokines such as leptin and adiponectin, and lipokines such as palmitoleate and fatty acid esters of hydroxyl fatty acids (FAHFA), to regulate systemic glucose and lipid metabolism [2-5]. Thus, AT dysfunction plays a pivotal role in the development of obesity and its associated diseases, including type 2 diabetes mellitus (T2DM), cardiovascular disease (CVD), non-alcoholic fatty liver disease (NAFLD), and several types of cancer [6-9]. Therefore, studies on ATs will provide opportunities to combat obesity-associated diseases $[10,11]$.

Fat accumulation is determined by the balance between TG synthesis and breakdown. Upon feeding, fatty acids in ATs are from two distinct origins, that is, circulating TG and de novo lipogenesis (DNL) [12]. Circulating TGs are originally synthesized in the intestine or liver, and packaged into chylomicrons or very low density lipoproteins (VLDL), respectively. When those lipoproteins travel to ATs, TGs are hydrolyzed into non-esterified fatty acids (NEFA) by insulin-stimulated action of lipoprotein lipase (LPL) within vascular endothelium in ATs [13]. Released NEFAs enter adipocytes through fatty acid transporters such as CD36 and fatty acid transport protein-1 (FATP1) [14,15]. Meanwhile, insulin also stimulates adipocyte glucose uptake, which drives DNL in adipocytes. Fatty acids from these two sources are esterified using glycerol 3-phosphate derived from glucose as a backbone to form TG that is stored in lipid droplets. 
During the periods of energy demand, that is, fasting or physical exercise, adipocytes mobilize stored fat to fulfill the energy need of other organs by lipolysis, in which each molecule of TG is broken down into three molecules of fatty acids and one molecule of glycerol. Three lipases act sequentially. First, adipose triglyceride lipase (ATGL) hydrolyzes TG into diacylglycerol (DAG) and the first molecule of fatty acid. Then, hormone-sensitive lipase (HSL) cleaves DAG into monoacylglycerol (MAG) and the second molecule of fatty acid. Ultimately, monoacylglycerol lipase (MGL) converts MAG into glycerol and the third molecule of fatty acid. These liberated fatty acids may be oxidized in muscle or brown adipose tissues (BAT), and glycerol may be used as a precursor for gluconeogenesis in the liver [16].

Under normal physiological conditions, lipogenesis and lipolysis are tightly and coordinately regulated by signals from peripheral tissues and the central nervous system, and both pathways are set into dynamic equilibrium to maintain fat content in ATs [17]. However, under pathological conditions, this equilibrium is disrupted. Consequently, unrestrained WAT lipolysis results in increased fatty acid release, leading to lipotoxicity and insulin resistance [18], while impaired lipogenesis in WAT decreases the synthesis of insulin-sensitizing fatty acid species, which also leads to insulin resistance [19]. As adipocyte lipolysis has been recently reviewed [16,20-22], here we focus on adipocyte lipogenesis and emphasize the recent progress in this field.

\section{De Novo Lipogenesis (DNL)}

Carbohydrates can be converted to fatty acids through the process of DNL. When energy is excessive in the body, most of the newly synthesized fatty acids are esterified to become TGs for storage. As shown in Figure 1, a series of coordinated enzymatic reactions are involved in the flow of carbons from glucose to fatty acids [23,24]. First, glucose derived from dietary carbohydrates undergoes glycolysis and tricarboxylic acid (TCA) cycle to produce citrate in the mitochondria, which is transported to cytosol and then releases acetyl-CoA by ATP-citrate lyase (ACLY). Second, the resulting acetyl-CoA is converted to malonyl-CoA by acetyl-CoA carboxylases 1 (ACC1). Third, fatty acid synthase (FASN), the key rate-limiting enzyme in DNL, converts malonyl-CoA into palmitate, which is the first fatty acid product in DNL. Finally, palmitate undergoes the elongation and desaturation reactions to generate the complex fatty acids, including stearic acid, palmitoleic acid, and oleic acid.

In principle, DNL takes place in all cells given the fact that fatty acids are the structural elements of cell membranes, but it is more active in metabolic tissues, such as liver, ATs, and skeletal muscle [25]. In rodents, liver is the major contributor to the whole-body lipogenesis, and ATs contribute much less than that of the liver. However, studies in humans fed with a carbohydrate-rich diet revealed that total fat synthesis in ATs significantly exceeded hepatic DNL [26], suggesting that ATs may be the second major site for fat synthesis. In particular, recent studies show that adipocytes generate adipocyte-specific fatty acids that act to improve systemic insulin sensitivity and decrease inflammation $[27,28]$. Therefore, adipocyte DNL is an important source of endogenous fatty acids and plays key roles in maintaining systemically metabolic homeostasis. Of note, although normally DNL in skeletal muscle is not a major contributor of total fatty acid flux in this tissue, it is induced under high-fat diet conditions [29]. Inhibition of DNL by skeletal muscle-specific FASN deletion improves systemic insulin sensitivity without altering adiposity, but decreases muscle strength [29], suggesting that DNL also plays important roles in skeletal muscle, especially in states of insulin resistance.

In addition to measuring lipogenic gene expression, several approaches have been used to trace fatty acid synthesis. One of the earliest approaches involved the use of radiolabeled substrates (e.g., ${ }^{14} \mathrm{C}$-acetate) to measure isotopic enrichment in the lipid fraction. The advantage of this approach is that it requires minimal sample preparation and no mass spectrometry. The downside, however, is that it is not specific to particular fatty acids, and thus does not provide information on isotope enrichment per molecule [30]. To overcome this shortage, approaches with increased specificity have been developed by combining stable isotope tracers with mass spectrometry analysis [31]. In this updated approach, deuterated water $\left(\mathrm{D}_{2} \mathrm{O}\right)$ is often used in cultured cells or animals. The principle 
of this approach is that the ${ }^{2} \mathrm{H}$ in $\mathrm{D}_{2} \mathrm{O}$ is incorporated into fatty acids during DNL and the degree of incorporation is directly proportional to the rate of biosynthesis. Using these approaches, DNL is directly studied.

DNL is highly controlled by hormones and nutritional status. During fasting, DNL is low, owing to increased blood glucagon and cellular cAMP levels, which inhibit DNL through activating AMP-activated protein kinase (AMPK) [32,33] and cAMP-dependent protein kinase (PKA) [34,35]. By contrast, after a carbohydrate-rich meal, blood glucose and insulin levels rise, which stimulate DNL through increasing the substrate availability, lipogenic enzymes activity, and lipogenic genes expression. It is noteworthy that food composition also has dramatic effects on DNL in ATs. For instance, fructoseor sucrose-rich diets strongly induce DNL in both liver and ATs. In contrast, high-fat diets significantly inhibit DNL $[36,37]$.

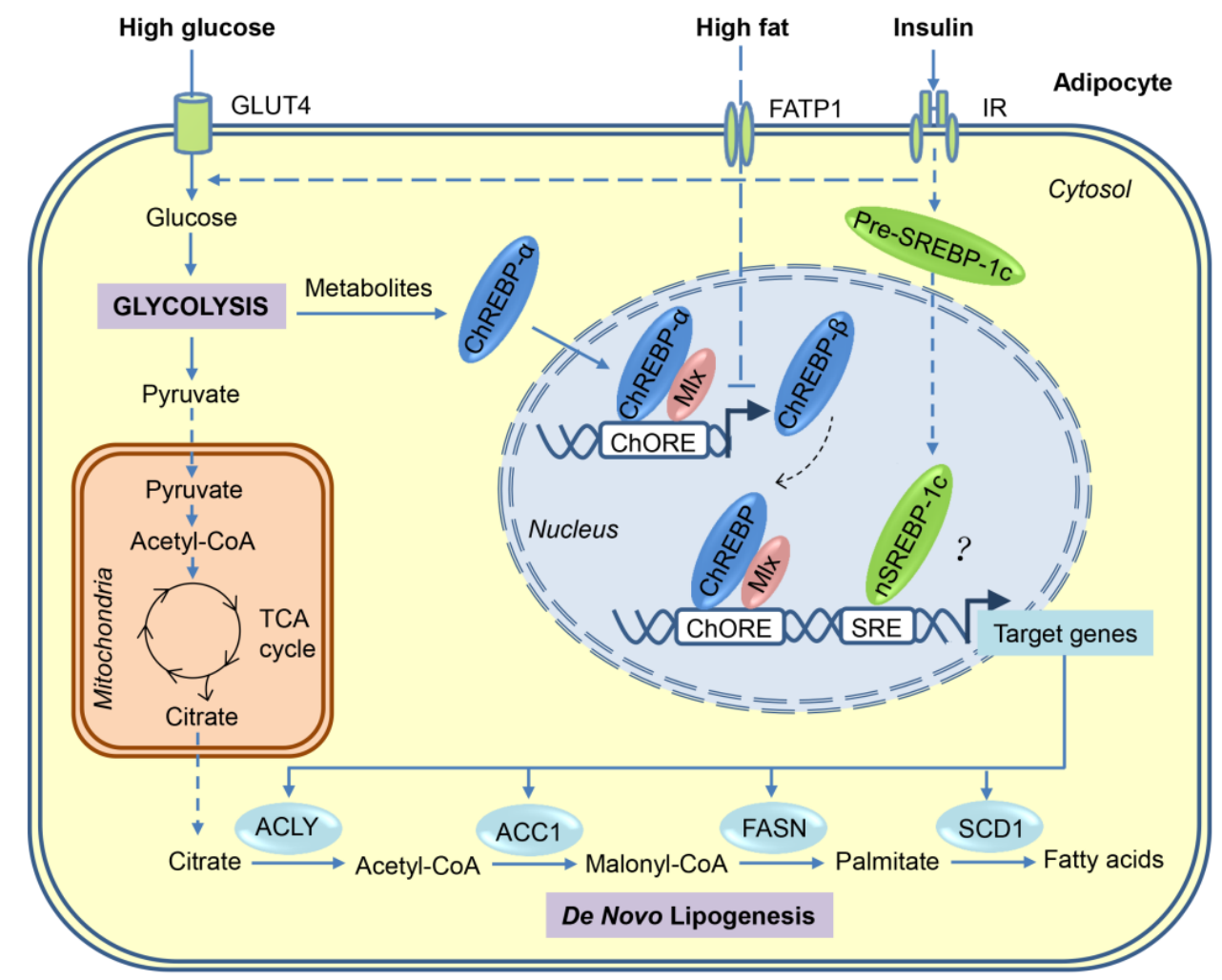

Figure 1. Transcriptional activation of de novo lipogenesis in adipocytes in response to high-sugar or high-fat diets. After the consumption of carbohydrates, a portion of the circulating glucose is taken by adipocytes through insulin-stimulated GLUT4, and then through glycolysis in the cytosol, glucose is converted to pyruvate, which is transported into mitochondria for further oxidation in the tricarboxylic acid (TCA) cycle. Citrate, an intermediate of the TCA cycle, is exported into cytosol and used as a substrate for de novo lipogenesis. Regulation of lipogenesis is mainly at the transcriptional level and carbohydrate response element-binding protein (ChREBP) plays a major role in adipocyte lipogenesis. Glucose metabolites generated during glycolysis activate ChREBP- $\alpha$, which, together with Max-like protein X (MLX), binds to the carbohydrate response elements (ChoRE) in the promoters of target genes, including those encoding ATP-citrate lyase (ACLY), acetyl-CoA carboxylases 1 (ACC1), fatty acid synthase (FASN), stearoyl-CoA desaturase-1 (SCD1), and ChREBP- $\beta$. The induced ChREBP- $\beta$ in turn further activates its target gene expression, which ultimately promotes the synthesis of fatty acids. Another lipogenic transcription factor sterol regulatory element-binding protein-1 (SREBP-1), induced by insulin at multiple levels, may play a minor role in adipocyte lipogenesis. Compared with carbohydrates, fat consumption inhibits de novo lipogenesis in adipocyte mainly through blocking the activation of ChREBP- $\beta$. FATP—fatty acid transport protein-1; IR-insulin receptor. 
Importantly, mammals have a limited capacity to store energy in the forms of carbohydrates, but are able to store seemingly unlimited amounts of TGs. Therefore, DNL plays a key role in the integration of glucose and lipid homeostasis. Dysregulation of DNL contributes to many metabolic problems, including hyperglycemia, hyperlipidemia, insulin resistance, T2DM, NAFLD, and CVD [23,38,39].

\section{Transcriptional Regulation of DNL in Adipocytes}

Many of the enzymes involved in DNL are regulated primarily at the transcriptional level in a coordinated manner. Transcriptional activation of these lipogenic genes after a carbohydrate-rich meal can be achieved through the complex mechanisms involving multiple transcription factors. Using loss/gain-of-function approaches, sterol regulatory element-binding protein (SREBP)-1, carbohydrate response element-binding protein (ChREBP), and liver $X$ receptors (LXRs) are identified as major lipogenic transcription factors in liver in response to insulin, glucose, and polyunsaturated fatty acids, respectively. However, only ChREBP seems to be the major driver for adipocyte DNL (Figure 1). The relevant data are also summarised in Tables 1 and 2.

\subsection{SREBP-1}

The SREBPs are a family of membrane-bound transcription factors that were identified as important regulators of cholesterol and fatty acid homeostasis [40]. In mammals, there are three SREBP isoforms (i.e., SREBP-1a, SREBP-1c, and SREBP-2) encoded by two different genes, named Srebf 1 and Srebf 2. SREBP-1a and SREBP-1c are derived from Srebf 1 by alternative splicing of the first exon. With a longer transactivation domain, SREBP-1a is transcriptionally more potent than SREBP-1c [41]. The third SREBP isoform, SREBP-2, is transcribed from a different gene Srebf 2 , but has a low homology with SREBP-1a/c [42]. Functionally, SREBPs activate distinct but overlapping programs in lipid metabolism. SREBP-1a activates both fatty acid and cholesterol synthesis, and SREBP-1c only induces fatty acid synthesis, whereas SREBP-2 is primarily responsible for cholesterol synthesis and uptake. Of the three SREBPs, SREBP-1c is more abundant in tissues with active DNL such as liver and ATs, and its function is predominantly regulated by insulin at multiple regulatory steps, including transcription, post-translation, and protein stability [43-45].

Transcriptionally, the Srebf1c mRNA is strongly induced by insulin via a mechanism involving the LXR transcription factors, as well as SREBP-1c feed-forward activation [46,47]. However, like SREBP-2, SREBP-1c is synthesized as an inactive membrane-bound precursor in the endoplasmic reticulum (ER). Maturation of SREBP-1c involves transportation of the precursor by the SREBP cleavage-activating protein (SCAP) from ER to Golgi, where the inactive precursor is cleaved sequentially by two proteases S1P and S2P [48]. The N-terminal fragment of SREBP-1c is then translocated into the nucleus and activates lipogenic gene expression. This is a highly regulated process, in which insulin plays a key role primarily through the activation of canonical PI3K/AKT pathway and the mammalian target of rapamycin complex 1 (mTORC1) [49]. A recent study shows that Per-Arnt-Sim (PAS) kinase is also required for SREBP-1c maturation and activation [50]. The mature/nuclear/active form of SREBP-1c is very unstable, and several factors are involved in the regulation of its protein stability. Insulin stabilizes the mature SREBP-1c through glycogen synthase kinase-3 $\beta$ (GSK-3 $\beta$ ) inhibition [51] and Lipin1 phosphorylation [52]. Moreover, our group found that CDK8, a subunit of the conserved Mediator complex that is down-regulated by insulin in the liver, negatively regulates the mature SREBP-1c protein stability by enhancing SREBP-1c phosphorylation and thus protein degradation [53].

Accumulating evidence suggests that SREBP-1c is a major regulator of hepatic DNL as it is both sufficient and necessary for DNL in the liver [54]. For example, pathological increase of SREBP-1c or genetic overexpression of SREBP-1c in the liver causes fatty liver [55,56]. Conversely, pharmacological inhibition or genetic inactivation of SREBP-1c protects from the development of fatty liver $[57,58]$. However, SREBP-1c seems to be a minor player for DNL in ATs. Although SREBP-1c is also both sufficient and necessary to promote lipogenic enzyme expression in adipocytes in vitro [59], global SREBP-1 knockout mice displayed normal mRNA levels of lipogenic enzymes 
in WATs when fed with the normal chow [60]. Moreover, despite the amelioration of fatty liver, loss of SREBP-1 in genetically obese $o b / o b$ mice also did not affect the lipogenic gene expression in WATs [57]. Interestingly, under the caloric restriction condition, SREBP-1c deficiency seemingly inhibits caloric restriction -induced upregulation of lipogenic genes in WATs, but not in the liver [61]. These loss-of-function studies suggest that SREBP-1c in adipocytes may not be important for DNL in vivo. One explanation is that the effect of SREBP-1 deficiency on DNL is compensated by other factors, particularly SREBP-2 [60]. However, a key caveat of those studies is that the animal models were global SREBP-1-deficient. To precisely define the importance of SREBP-1c in adipose tissues, adipocyte-specific SREBP-1c-deficient mouse models, that is, SREBP-1c knockout in Adiponectin (Adipq)-positive cells, are required in the future.

In addition, it has been reported that an increase of SREBP-1c expression in WATs by the treatment of LXR agonist T0901317 is not accompanied by the up-regulation of lipogenic genes such as FASN, ACC1, and stearoyl-CoA desaturase-1 (SCD1) [62]. Consistent with the gene expression, SREBP-1c was neither recruited to the Fasn promoter nor did it induce the activity of a Fasn promoter-driven reporter gene in adipocytes [62]. Moreover, SREBP-1c transgenic mice driven by the aP2 (Fabp4) promoter also did not display an increase of lipogenic gene expression in WATs, although some lipogenic genes such as Fasn, Acc1, and $S c d 1$ were up-regulated in BAT [63]. However, it is unclear whether these effects are direct or indirect because the transgenic mice also exhibit impaired adipocyte differentiation, severe AT lipodystrophy, insulin resistance, and fatty liver [64]. Together, these gain-of-function studies also argue against SREBP-1c as a major driver for adipocyte DNL. By contrast, fat-specific overexpression of SREBP-1a, which is much lower in abundance than SREBP-1c in ATs, significantly increased lipogenic genes expression and fatty acid synthesis in both WAT and BAT, leading to ATs hypertrophy [63]. This result suggests that SREBP-1a and SREBP-1c have distinct roles in adipocyte fat metabolism in vivo. Nonetheless, a caveat of those studies is that the aP2 promoter is active not only in adipocytes, but also in macrophages [65]. As macrophages in ATs are known to play a regulatory role in metabolism [66,67], the aP2 promoter used in these studies may have complicated the results. Therefore, future studies using adipocyte-specific promoters to overexpress SREBP-1c may be necessary.

\subsection{ChREBP}

ChREBP, also known as MLXIPL or MONDOB, is a member of basic helix-loop-helix/leucine zipper transcription factor family that is responsible for carbohydrate-induced transcription of glycolytic and lipogenic enzymes [68,69]. It has two isoforms, ChREBP- $\alpha$ and the recently identified ChREBP- $\beta$, which is encoded by the same Mlxipl gene, but through the use of alternative promoters [70].

ChREBP- $\alpha$ is constitutively expressed in metabolically-active tissues, such as liver, adipose tissues, skeletal muscle, intestine, kidney, and pancreas [68], but during fasting or under low glucose conditions, ChREBP- $\alpha$ was phosphorylated by PKA [35] and AMPK [33] at multiple sites to retain it in the cytosol. During feeding or high glucose conditions, the intermediates of glucose metabolism, such as xylulose 5-phosphate or glucose 6-phosphate, activate ChREBP- $\alpha$ through multiple insulin-independent mechanisms, including dephosphorylation, nuclear translocation, protein-protein interactions, and release of the transactivation domain inhibition [71-73]. Upon activation, ChREBP- $\alpha$ forms a heterodimer with MLX and induces the expression of genes primarily involved in glycolysis, DNL, and fatty acid desaturation $[68,74]$. In contrast, ChREBP- $\beta$ isoform, which lacks most of the N-terminal low glucose-inhibitory domain, is constitutively active in stimulating target gene expression, and its transcription is induced in a feed-forward manner by ChREBP- $\alpha$ and itself (Figure 1) [70]. To date, other regulators that control the expression of ChREBP- $\beta$ remain unknown.

In agreement with its function in the liver (reviewed by authors of [75]), ChREBP is also a major determinant of fatty acid synthesis in ATs. ChREBP- $\alpha$ is highly expressed in both WAT and BAT in human, mouse, and rat. It is also expressed in preadipocytes, and its level increases 
dramatically during differentiation of human and mouse preadipocytes [76,77]. Overexpression of a constitutively active ChREBP in mouse 3T3-L1 white preadipocytes increases lipogenic gene expression and promotes adipocyte differentiation [77]. Conversely, reducing endogenous ChREBP activity impairs adipocytes differentiation [77]. Mechanistically, it is suggested that some unknown fatty acid derivatives from ChREBP-mediated DNL are required for the activation of nuclear receptor peroxisome proliferator-activated receptor (PPAR $\gamma$ ), the master transcription factor in adipogenesis [77]. In support of this model, supplement of the PPAR $\gamma$ ligand, rosiglitazone, can completely rescue the differentiation defect caused by ChREBP deficiency, including adipogenic and lipogenic marker genes expression and lipid accumulation [19].

Consistent with the in vitro results, overexpression of constitutively active ChREBP isoform in adipose tissues increased the expression of genes involved both in DNL such as Fasn, Acly, Acc1, Scd1, and Elovl6, and adipocyte differentiation such as Pparg2, Cebpa, and Fabp4 [78]. Conversely, mice with global ChREBP deficiency displayed significant impairment of lipogenic gene expression and hepatic DNL; these mice are intolerant to simple carbohydrates and develop insulin resistance [68]. Although the authors did not examine DNL in fat, the weights of both WAT and BAT from ChREBP-deficient mice were dramatically reduced [68], suggesting that adipocyte DNL is probably also impaired. This speculation was confirmed by a recent study, in which adipocyte-specific ChREBP-mutant mice were studied, and loss of ChREBP in fat dramatically impaired sucrose-induced lipogenic gene expression and DNL in both WAT and BAT, but not in the liver [19]. However, compared with global ChREBP-deficiency, adipocyte-specific ChREBP-deficiency had little effect on the weights and sizes of adipose tissues, regardless of whether the mice were fed with the normal chow diet or high-fat diet $[19,68]$. This is probably because of the compensatory effects of increased fatty acids uptake from the circulation. Although further studies are needed, it is clear that unlike SREBP-1c, ChREBPs are both necessary and sufficient to drive DNL in adipocytes.

Consistent with the conclusion that ChREBPs are the major lipogenic transcription factors in ATs, the upstream lipogenic signals or other lipogenic factors in adipocyte regulate DNL directly or indirectly through the regulation of ChREBP expression or transcriptional activity. GLUT4 (also known as SLC2A4), the major glucose transporter in adipocytes, determines the activity and expression of ChREBPs through the regulation of glucose uptake. Adipocyte-specific overexpression of GLUT4 increased lipogenic enzyme expression, fatty acid synthesis, lipid accumulation, and adiposity through ChREBP- $\alpha$-mediated induction of ChREBP- $\beta$ expression, but not through SREBP-1c [70]. Conversely, Adipocyte-specific knockout of GLUT4 resulted in opposite effects [70]. mTORC2 is a master regulator of metabolism and controls DNL in both WAT [37] and BAT [79]. Conditional deletion of the essential mTORC2 subunit RICTOR in mature adipocytes reduced ChREBP- $\beta$ expression and DNL in WAT partially through the downregulation of GLUT4-mediated glucose uptake [37]. Intriguingly, inhibiting adipocyte lipid uptake by conditional deletion of LPL resulted in a compensatory increase of DNL in both WAT and BAT owing to the up-regulation of the GLUT4/ChREBP- $\beta$ pathway [80]. More recently, the serine/threonine-protein kinase AKT2, an effector molecule in the insulin signaling pathway, has been identified as a cold-induced kinase in BAT that is required for adipocyte DNL by stimulating the ChREBP- $\beta$ transcriptional activity [36]. Collectively, these studies strongly suggest that the ChREBP transcription factors are the major activators of DNL in adipocytes.

\subsection{LXRs}

The oxysterol-activated nuclear receptor LXRs, that is, $\operatorname{LXR} \alpha$ and $\operatorname{LXR} \beta$, were initially characterized as key regulators of hepatic cholesterol and lipid metabolism [81]. LXR $\alpha$ and LXR $\beta$ are encoded by two different genes, but share a considerable sequence homology [82]. LXR $\alpha$ is expressed primarily in liver, ATs, intestine, and macrophages [83], whereas LXR $\beta$ is ubiquitously expressed [84]. Upon binding to ligands, LXRs undergo a conformational change that promotes interaction with coactivators to facilitate transcription of target genes. Like other nuclear receptor family members, LXRs are modulated by a wide range of post-translational modifications, including SUMOylation, 
phosphorylation, acetylation, ubiquitination, and O-GlcNAcylation [85]. For example, under fasting condition, hepatic $\mathrm{LXR} \alpha$ is directly phosphorylated by PKA, which impairs LXR $\alpha$ DNA binding activity and inhibits the expression of its target genes such as SREBP-1c [86].

The functions of LXRs have been well studied in the liver. They stimulate hepatic DNL by direct activation of the promoters of lipogenic genes such as Srebf1c and Fasn [47]. Activation of LXRs in mice by oral administration of a synthetic LXR agonist T0901317 led to a marked increase in SREBP-1 and lipogenic enzyme expression, as well as TG content in the liver [46]. In agreement with this study, another study reported that mice developed fatty liver in three weeks after the treatment with T0901317 by intraperitoneal injection under high-fat diet conditions [87]. Furthermore, global loss of LXRs in $o b / o b$ mice impairs hepatic lipogenesis and reduces hepatic steatosis compared with control because of the decreased expression of SREBP-1 and lipogenic enzymes [88].

Table 1. Summary of loss-of-function studies for major lipogenic transcription factors.

\begin{tabular}{|c|c|c|c|}
\hline TF & Loss of Function & Phenotypes & References \\
\hline \multirow{3}{*}{ SREBP-1 } & Global & $\begin{array}{l}\text { Decreased hepatic lipogenesis, while increased hepatic } \\
\text { cholesterol synthesis due to elevated SREBP-2 in liver; } \\
\text { No effect on adiposity and lipogenic enzymes expression } \\
\text { in WAT. }\end{array}$ & $\begin{array}{l}\text { Shimano et al., } \\
\quad 1997 \text { [60] }\end{array}$ \\
\hline & Adipose tissues & Not available & Not available \\
\hline & Liver & $\begin{array}{l}\text { Decreased hepatic lipogenesis, abolished sucrose-induced } \\
\text { hypertriglyceridemia, and prevented hepatic steatosis in } o b / o b \\
\text { mice and HFD-fed mice, despite persistent obesity, } \\
\text { hyperinsulinemia, and hyperglycemia. }\end{array}$ & $\begin{array}{l}\text { Moon, et al., } \\
2012[58]\end{array}$ \\
\hline \multirow{3}{*}{ ChREBP } & Global & $\begin{array}{l}\text { Decreased hepatic lipogenesis and glycolysis; Increased } \\
\text { hepatic glycogen level; Reduced adiposity; Impaired insulin } \\
\text { sensitivity and glucose tolerance. }\end{array}$ & $\begin{array}{l}\text { Iizuka et al., } \\
2004[68]\end{array}$ \\
\hline & Adipose tissues & $\begin{array}{l}\text { Decreased sucrose-induced lipogenesis in adipose tissue but } \\
\text { not in the liver; Decreased PAHSAs level in serum; Impaired } \\
\text { insulin sensitivity and glucose tolerance. }\end{array}$ & $\begin{array}{l}\text { Vijayakumar } \\
\text { et al., } 2017 \text { [19] }\end{array}$ \\
\hline & Liver & $\begin{array}{l}\text { No effects on hepatic lipogenesis, but altered expression of } \\
\text { lipogenic genes in liver, WAT and BAT; Protected from } \\
\text { high-carbohydrate diet induced hepatic steatosis, but with } \\
\text { increased hepatic glucose production and impaired hepatic } \\
\text { insulin sensitivity and systemic glucose tolerance; Reduced } \\
\text { WAT mass and adipocyte size. }\end{array}$ & $\begin{array}{l}\text { Jois et al., } \\
2017[89]\end{array}$ \\
\hline \multirow{3}{*}{ LXRs } & Global & $\begin{array}{l}\text { Decreased hepatic lipogenesis and protected from hepatic } \\
\text { steatosis; Impaired } \beta \text {-cell expansion and glucose tolerance; } \\
\text { Improved insulin sensitivity due to increased WAT } \\
\text { lipogenesis and WAT mass. }\end{array}$ & $\begin{array}{l}\text { Beaven et al., } \\
2013[88]\end{array}$ \\
\hline & Adipose tissues & $\begin{array}{l}\text { Increased adipocyte size and adiposity by decreasing WAT } \\
\text { lipolytic and oxidative capacities. }\end{array}$ & $\begin{array}{l}\text { Dib et al., } \\
2014[90]\end{array}$ \\
\hline & Liver & Not available & Not available \\
\hline
\end{tabular}

Abbreviation: TF-transcription factor; SREBP—sterol regulatory element binding protein; ChREBP—carbohydrate response element binding protein; LXRs-liver X receptors. WAT-white adipose tissues; BAT-brown adipose tissues; HFD—high-fat diet; PAHSAs—-palmitic acid ester of hydroxyl stearic acids.

However, the published data suggest that LXRs may target different pathways in adipocytes. In contrast to those results from the liver, global loss of LXRs in $a b / o b$ mice significantly enhanced lipogenesis and adipogenesis in ATs, leading to enlarged fat tissues and improved insulin sensitivity [88]. This is probably owing to the up-regulation of the PPAR $\gamma$ and GLUT4/ChREBP- $\beta$ pathways [88]. In agreement with this report, adipose tissue-specific $\mathrm{LXR} \alpha$ knockout mice also had severe adiposity with a concomitant increase in fat mass and adipocyte size when fed with a high-fat diet [90]. The underlying mechanism is probably that $\mathrm{LXR} \alpha$ deficiency in fat impairs adipocyte lipolysis and fatty acid availability and oxidation [90]. Conversely, administration of LXR $\alpha$ agonist T0901317 in mice fed with a high-fat diet reduced fat mass, which was accompanied with increased adipocyte 
lipolysis and apoptosis, and decreased PPAR $\gamma$ transcriptional activity [87]. Although different mouse models and diets may contribute to the different effects of LXRs in ATs, these studies suggest that LXRs play a different role in adipocytes and hepatocytes. Nonetheless, it is less likely that LXRs are major regulators of DNL in adipocytes.

Table 2. Summary of gain-of-function studies for major lipogenic transcription factors.

\begin{tabular}{|c|c|c|c|}
\hline TF & Gain of Function & Phenotypes & References \\
\hline \multirow{2}{*}{ SREBP-1c } & Adipose tissues & $\begin{array}{l}\text { Impaired adipocytes differentiation, markedly reduced } \\
\text { adiposity; Increased fatty liver development; Impaired insulin } \\
\text { sensitivity and glucose tolerance. }\end{array}$ & $\begin{array}{l}\text { Shimomura et al., } \\
1998 \text { [64] }\end{array}$ \\
\hline & Liver & $\begin{array}{l}\text { Increased hepatic lipogenesis and fatty liver development; } \\
\text { Increased visceral adipose tissue mass; Impaired insulin } \\
\text { sensitivity. }\end{array}$ & $\begin{array}{l}\text { Knebel et al., } \\
2012[56]\end{array}$ \\
\hline \multirow[t]{2}{*}{ SREBP-1a } & Adipose tissues & $\begin{array}{l}\text { Increased adipose tissue lipogenesis and adipocyte } \\
\text { hypertrophy; Enhanced fatty acid secretion and fatty } \\
\text { liver development. }\end{array}$ & $\begin{array}{l}\text { Horton et al., } \\
2003 \text { [63] }\end{array}$ \\
\hline & Liver & $\begin{array}{l}\text { Increased hepatic lipogenesis and cholesterol synthesis, } \\
\text { and enhanced fatty liver development. }\end{array}$ & $\begin{array}{l}\text { Shimano et al., } \\
1996[91]\end{array}$ \\
\hline \multirow{2}{*}{ ChREBP } & Adipose tissues & $\begin{array}{l}\text { Increased adipose tissue lipogenesis; Reduced adiposity; } \\
\text { Protected from HFD-diet induced fatty liver; Improved } \\
\text { insulin sensitivity and glucose tolerance. }\end{array}$ & $\begin{array}{l}\text { Nuotio-Antar } \\
\text { et al., } 2015 \text { [78] }\end{array}$ \\
\hline & Liver & $\begin{array}{l}\text { Increased hepatic glycolysis and lipogenesis, enhanced fatty } \\
\text { liver development; Decreased visceral adipose tissue mass; } \\
\text { Improved hepatic insulin signaling and systemic } \\
\text { glucose tolerance. }\end{array}$ & $\begin{array}{l}\text { Benhamed et al., } \\
\quad 2012[92]\end{array}$ \\
\hline LXRs & Global & $\begin{array}{l}\text { Increased hepatic lipogenesis and enhanced fatty liver } \\
\text { development; Increased WAT lipolysis and apoptosis, } \\
\text { and decreased fat mass; Impaired insulin sensitivity but not } \\
\text { glucose tolerance. pharmacological treatment }\end{array}$ & $\begin{array}{l}\text { Dong et al., } \\
2017 \text { [87] }\end{array}$ \\
\hline
\end{tabular}

\section{Post-Translational Regulation of DNL in Adipocytes}

As discussed above, most enzymes involved in DNL are primarily regulated at the transcriptional level, however, the activities or protein stability of these enzymes are also regulated at the post-translational level. During fasting, the lipogenic enzymes are restrained at low activities. In response to feeding, their enzymatic activities are acutely increased by post-translational modifications, including phosphorylation and O-GlcNAcylation.

Phosphorylation is a common post-translational modification of proteins. Recently, it has been reported that phosphorylation of ACLY, the first enzyme in DNL, is dynamically regulated by the hepatic branched chain alpha-keto acid dehydrogenase kinase (BDK) and protein phosphatase $\mathrm{Mg}^{2+} / \mathrm{Mn}^{2+}$-dependent 1K (PPM1K) [93], which are previously known to control branched-chain $\alpha$-ketoacid dehydrogenase (BCKDH) activity and branched-chain amino acids (BCAA) levels. Phosphorylation of ACLY on Ser454 by BDK increases the ACLY activity for the generation of acetyl-CoA and subsequent malonyl-CoA, eventually promoting hepatic DNL. Importantly, this modification is physiologically regulated during the fasting-feeding cycle by ChREBP- $\beta$, which up-regulates BDK expression and concomitantly inhibits PPM1K expression during feeding [93]. Thus, after a carbohydrate-rich meal, ChREBP not only directly stimulates the Acly gene transcription, but also enhances the activity of ACLY through modulating the ratio of BDK to PPM1K. However, so far it is still unclear whether ACLY in adipocytes is also regulated by BDK and PPM1K. In contrast, phosphorylation inhibits the activities of ACC1 and FASN. The serine/threonine kinase AMP-activated protein kinase (AMPK) acts as a major energy sensor and regulator in ATs [94]. When activated by intracellular energy depletion, nutrient deprivation, or hypoxia, AMPK phosphorylates ACC1 at Ser79 and FASN at unknown site(s) in adipocytes, leading to direct inhibition of the production of malonyl-CoA and palmitate, respectively. Consequently, DNL is 
inhibited by the activation of AMPK [95-97]. O-GlcNAcylation is a highly dynamic post-translational modification, which is controlled by two antagonistic enzymes: O-Linked N-Acetylglucosamine (O-GlcNAc) transferase (OGT), which transfers the GlcNAc group onto serine or threonine residues of protein substrates [98]; and O-GlcNAcase (OGA), which removes the sugar moiety from substrates [99]. A recent study reported that FASN is directly modified by O-GlcNAcylation in the liver [100]. Elevating O-GlcNAcylation of FASN by glucose-induced activation of OGT or drug-targeted inhibition of OGA increases the interaction between FASN and ubiquitin-specific protease-2a (USP2A), which acts to remove ubiquitination and is known to stabilize FASN [101]. As a result, O-GlcNAcylation of FASN leads to accumulation of this enzyme and DNL in the liver [100]. Although O-GlcNAcylation of FASN in adipocytes has not been reported to date, given the fact that O-GlcNAc modification is involved in development of insulin resistance and glucose-toxicity in adipocytes [102,103], it is possible that adipocyte FASN is also regulated by O-GlcNAcylation. However, whether other lipogenic enzymes are regulated by O-GlcNAcylation or other modifications such as acetylation is currently unclear and deserves to be investigated in the future.

\section{Central Regulation of DNL in Adipocytes}

A growing number of studies have demonstrated that adipocyte DNL is not only regulated by the peripheral signals, but also by the central nervous system [104,105]. To date, insulin and leptin are two reported signals in medial basal hypothalamus (MBH) that play a key role in maintaining DNL in WATs [106].

Insulin has a direct effect on adipocyte DNL through the insulin receptor, which leads to the activation of PI3K-AKT signaling pathway and inhibition of PKA [43]. However, studies also point to an indirect role of insulin on DNL through MBH [107]. When the insulin level is acutely raised in the brain by infusing insulin directly into $\mathrm{MBH}$ of rats, the expression of lipogenic enzymes including Fasn and DNL in WATs were increased, while the activity of HSL and adipocyte lipolysis were suppressed [107]. Conversely, mice lacking the neuronal insulin receptor exhibit decreased DNL and unrestrained lipolysis in WATs [107]. Mechanistically, MBH insulin signals likely inhibit sympathetic outflow to WATs, as surgical denervation or pharmacological sympathectomy abolishes the effects of brain insulin on WAT lipogenesis and lipolysis [107]. In contrast, leptin, an adipokine that plays a key role in the control of body weight through regulating food intake and fuel partitioning, was found to exert an effect opposite to insulin in $\mathrm{MBH}$ [108]. Acute infusion of leptin into MBH of rats inhibits lipogenic enzyme expression and DNL, but activates lipolysis in WATs [108]. This is probably because the $\mathrm{MBH}$ leptin signaling is able to reduce the endocannabinoid anandamide level in WATs via sympathetic innervation [108]. It has been shown that anandamides can stimulate lipogenesis by activating the cannabinoid receptors [109]. Supporting this mechanism, when the rats were treated with the cannabinoid receptor agonist Win 55,212-2, MBH leptin failed to suppress DNL in WATs [108]. Furthermore, surgical denervation also blocks the inhibitory effect of MBH leptin on WAT lipogenesis [108]. Taken together, MBH insulin stimulates DNL and suppresses lipolysis in WATs, whereas MBH leptin acts oppositely, and these effects are mediated through either stimulation or inhibition of the sympathetic outflow to WATs [106-108].

Apart from insulin and leptin, a newly-identified neuropeptide, neurosecretory protein GL (NPGL), is reported to be involved in adipocyte DNL [110]. NPGL infusion or overexpression in MBH induced DNL specifically in WATs, but not in liver, and also increased the size of white adipocytes and adiposity [110]. Conversely, administration of neutralizing antibody against NPGL decreased white adipocyte size [110]. However, unexpectedly, NPGL mRNA expression is induced by fasting and inhibited by insulin [110]. As both insulin and NPGL promote adipocyte DNL, insulin inhibition of NPGL expression may constitute a negative feedback mechanism in MBH to curb adipocyte DNL in order to avoid adipocyte hypertrophy. To date, it remains unclear whether there are other signals in the central nervous system that can regulate adipocyte DNL. 


\section{Role of Adipocyte DNL in Insulin Resistance}

A number of studies indicate that DNL in ATs has both direct and indirect beneficial effects to the body [111]. An increase in DNL promotes the conversion of excessive carbohydrates into fatty acids for energy storage. This pathway is of physiological importance especially when the diet is rich in carbohydrates, because hyperglycemia causes cellular damages and organ dysfunctions due to glucotoxicity [112,113]. Therefore, DNL helps to maintain glucose homeostasis. Moreover, adipocyte DNL is involved in the regulation of systemic glucose and lipid metabolism through the generation of lipokines [5,27].

\subsection{DNL in White Adipocytes}

Different from the changes in the liver, DNL is usually decreased in fat when animals or humans are obese or insulin resistance [114-117]. Based on the available data, such reduction seems to be a causative factor for the development of insulin resistance. For example, a recent study shows that adipocyte-specific reduction of DNL by ChREBP knockout causes insulin resistance and inflammation [19]. Therefore, adipocyte DNL is important for maintaining systemic insulin sensitivity. Interestingly, these beneficial effects of DNL in fat are found to be exerted by producing insulin-sensitizing fatty acids, such as palmitoleate and FAHFAs (Figure 2) [118,119].

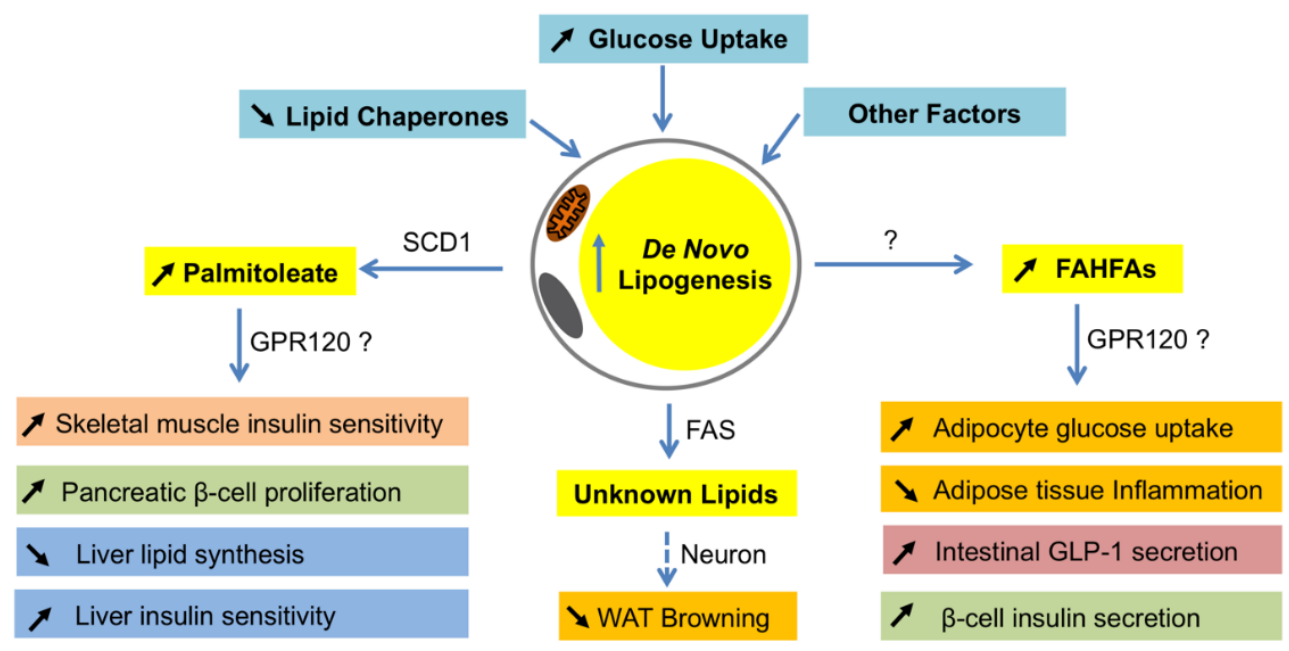

Figure 2. Systemic effects of lipokines produced by de novo lipogenesis in adipocytes. When de novo lipogenesis is increased in adipocytes by means of increasing glucose uptake, decreasing lipid chaperones, or others, some bioactive fatty acids such as palmitoleate and fatty acid ester of hydroxyl fatty acids (FAHFAs) are produced. As a product of SCD1 in adipocytes, palmitoleate functions to improve insulin sensitivity in skeletal muscle and liver, promote pancreatic $\beta$-cell proliferation, and inhibit lipid synthesis in the liver. Although it is unclear how FAHFAs are synthesized in adipocytes, these lipids have a function to stimulate adipocyte glucose uptake, intestinal glucagon-like peptide-1 (GLP-1) secretion and $\beta$-cell insulin secretion, and reduce inflammation in adipose tissues. The metabolically beneficial effects of palmitoleate and FAHFAs are probably through G protein-coupled receptor 120 (GPR120). In addition, FASN may produce some unknown lipid products in white adipocytes that function to inhibit white fat browning through neuronal circuit regulation. WAT—white adipose tissues.

Palmitoleate, a 16-carbon monounsaturated fatty acid, is produced mainly in adipocytes by FASN-mediated synthesis of palmitate, followed by SCD1-catalyzed desaturation [120]. Palmitoleate was first described as an insulin-sensitizing lipokine when the researchers examined the mice with a combined loss of fatty acid-binding proteins FABP4/aP2 and FABP5 [118]. Those mice were protected from high fat diet-induced obesity and fatty liver, and displayed profound insulin sensitivity and altered lipid profiles [118]. To determine if a specific lipid was correlated with the insulin sensitivity 
in those mice, an unbiased lipidomics approach was used to examine the lipid profiles of WAT and identified palmitoleate (C16: $1 n 7)$, which was the most significantly elevated lipid in adipose tissues, as well as serum. When wildtype mice were treated with palmitoleate, their muscle insulin sensitivity was increased while hepatic DNL was suppressed, suggesting that palmitoleate functions as a circulating lipokine and has insulin sensitizing effects [118]. Supporting the metabolic role of palmitoleate, G protein-coupled receptor 120 (GPR120) knockout mice had a reduced SCD1 expression in adipose tissues and lower levels of palmitoleate in plasma and adipose tissues, and those animals displayed lower insulin sensitivity with reduced phosphorylation of the insulin receptor, insulin receptor substrates, and protein kinase B in muscle, liver, and fat [74]. Subsequent studies in rodents further uncovered more fascinating roles of palmitoleate in metabolism (reviewed in the works of [121,122]).

However, the data on palmitoleate in humans are mixed. One study reported that circulating palmitoleate levels strongly and independently predict the insulin sensitivity of individuals at the high risk for T2DM [123]. In addition, human primary adipocytes extracted from the gluteofemoral depot showed higher production and release of palmitoleate compared with those from the abdominal depot, which was correlated with better insulin sensitivities and higher Scd1 expression [75]. Whereas, another study found that decreased palmitoleate in plasma and in VLDL is not associated with insulin resistance in skeletal muscle, liver, or adipose tissues in obese people [124]. Moreover, it is reported that palmitoleate is not related to insulin sensitivity in type 1 diabetes [125]. These discrepancies are probably the result of the analyses of different lipid fractions from different tissues or diseases. Nevertheless, palmitoleate represents an important link between adipocyte DNL and systemic insulin resistance.

Fatty acid esters of hydroxy-fatty acids or FAHFAs are another molecular link between adipocyte DNL and insulin resistance. Studies of adipocyte-specific GLUT4 transgenic (AG4OX) mice revealed that despite being obese and having elevated circulating fatty acids, those mice were more glucose tolerant and DNL in fat was elevated [119]. Lipidomic analysis of WATs from AG4OX mice led to the discovery of a new class of lipids, called FAHFAs, which were elevated in WATs and serum of AG4OX mice, and have beneficial effects in metabolism [119] (reviewed by authors of [126]). The most abundant forms of FAHFA in serum and fat of AG4OX mice are palmitic acid ester of hydroxyl stearic acids (PAHSA), and of which 9-PAHSA is the most abundant and biologically active isomer in adipose tissues [119]. Treatment of obese mice with 9-PAHSA lowers blood glucose and improves glucose tolerance, while stimulating insulin secretion in pancreas and glucagon-like peptide 1 secretion in intestinal cells, as well as insulin-stimulated glucose transport in adipocytes [19]. Inflammatory cytokine production from immune cells and ameliorate adipose inflammation in obesity is also reduced by 9-FAHFA [119]. The levels of FAHFAs are dynamically regulated by physiological and pathophysiological conditions. Fasting and high-fat diet feeding in mice alters the levels of FAHFAs in fat and serum in a tissue-specific and/or isomer-specific manner [119]. Interestingly, serum FAHFA levels are highly correlated with insulin sensitivity in humans [119]. Although the functions of FAHFAs in humans are still unclear, they represent another important link between adipocyte DNL and systemic insulin sensitivity.

The synthesis of FAHFAs in adipocytes is induced by the GLUT4/ChREBP-mediated DNL. First, the expression of GLUT4 and ChREBP- $\beta$ in ATs are also reduced in obese mice and humans, and highly correlated with insulin sensitivity in humans $[70,111]$. Second, the detrimental effects of adipocyte-specific ChREBP knockout, in which PAHSAs were reduced, on insulin sensitivity and inflammatory responses can be completely abolished by 9-PAHSA supplementation [19]. Third, adipocyte-specific overexpression of ChREBP- $\beta$ improved insulin sensitivity and reduced inflammatory genes expression in response to a Western diet [78]. Of note, the production of PAHSAs and palmitoleate may be regulated in different manners, as in RICTOR-knockout mice, the GLUT4/ChREBP-mediated DNL was inhibited, but somehow palmitoleate was elevated in WATs [37]. This is probably a compensatory response to the reduction of PAHSAs. Although 
the molecular mechanisms underlying the insulin-sensitizing effects of PAHSAs remain unclear, GPR120 seems to be involved [119].

It is unclear whether there are other lipokines that also exert an insulin-sensitizing effect, and how these lipokines may act and interplay in states of insulin resistance. Future studies are necessary to address these important questions. Interestingly, the metabolic benefits of elevated DNL in adipocytes may depend on how DNL is induced. For example, specific inhibition of fatty acids uptake in ATs by genetic ablation of LPL, the master regulator of fatty acid uptake from triglyceride-rich lipoproteins, caused a profound increase of DNL in both WAT and BAT, a reduction of adiposity, and an improved profile of blood insulin and adipokines [80]. However, neither glucose tolerance nor inflammatory markers were ameliorated in those mice [80]. One possible explanation is that loss of LPL potentially eliminates certain essential fatty acids from diets [80]. This may counteract the beneficial effects of increased DNL in adipocytes.

\subsection{DNL in Brown Adipocytes}

Although BAT has a higher rate of DNL than WAT [19], and FAHFAs are also synthesized in BAT [118], the contribution of DNL in BAT to whole body insulin sensitivity seems to be limited. A recent study has shown that inhibition of ChREBP-mediated DNL in BAT by AKT2 knockout remodeled the global lipid landscapes and reduced lipid content in BAT, but glucose and insulin tolerance as well as body mass were not affected [36]. Consistent with this study, BAT-specific knockout of FASN also did not affect glucose tolerance under both normal chow and high-fat diet conditions [114]. One possibility is that the BAT mass is quantitatively much less than that of WATs so that BAT contributes only a small portion of total beneficial lipokines in the body. Another possibility is that lipokines produced by BAT may be different from those by WATs. Recent studies identified a BAT-specific lipokine, 2,13-diHOME, which promotes fatty acid uptake by BAT and skeletal muscle in response to cold and exercise, respectively $[127,128]$. Notably, 2,13-diHOME is not synthesized through DNL in BAT, but using linoleic acid, an essential fatty acid that can be obtained only from diets $[127,128]$. Together, the published data on adipocyte DNL suggest that DNL in WAT, but not BAT, plays an important role in the regulation of insulin sensitivity.

\section{Role of Adipocyte DNL in Thermogenesis}

In addition to the regulation of insulin sensitivity, emerging evidence indicates that DNL is also involved in thermogenesis by ATs. There are at least two types of thermogenic adipocytes, that is, brown adipocytes and cold-induced beige adipocytes, both of which are also considered to play an important role in the control of body weight and glucose homeostasis [129-131].

\subsection{DNL in Thermogenesis of BAT}

It is well-known that BAT plays a critical role in cold-induced thermogenesis and maintenance of euthermia [132,133]. Interestingly, although DNL in BAT is significantly induced by cold conditions, it is not essential for cold-induced thermogenesis [36]. BAT-specific loss of AKT2 disrupted ChREBP-mediated DNL in BAT, leading to impaired lipid accumulation in brown adipocytes [36]. However, those mice displayed normal heat production and the ability to maintain body temperature in response to the acute cold challenge [36]. Consistent with this study, mice with BAT-specific FASN deficiency also maintained euthermia and showed normal thermoregulation in response to cold conditions [134]. In fact, BAT lipolysis is also recently reported to be non-essential for cold-induced thermogenesis, as a result of a compensatory combustion of fuels derived from diets or lipolysis of white fat and cardiac muscle $[135,136]$. Thus, it seems that both lipogenesis and lipolysis in BAT are dispensable for acute cold-induced thermogenesis. However, under chronic cold adaptation, it has been shown that specific impairment of lipogenesis or lipolysis in BAT results in a compensatory response of increased WAT browning [36,136], suggesting both BAT lipogenesis and lipolysis are required for optimizing fuel storage and thermogenesis. 


\subsection{DNL in WAT Browning}

The so-called WAT browning is a process in which beige adipocytes are formed in WATs in response to cold exposure or sympathetic agonist stimulation. It has several benefits, including reduction of body weight and improvement of insulin sensitivity. Recent studies indicate that DNL also plays a role in WAT browning. Contrary to the beneficial effects of adipocyte DNL described above, loss of the key lipogenic gene FASN unexpectedly stimulates the appearance of beige adipocytes in subcutaneous WAT (iWAT) in mice. When FASN is constitutively depleted in adipocytes, the mice displayed an increase in energy expenditure and cold resistance correlated with the increase of beige adipocytes in iWAT [137]. Moreover, fat-specific FASN knockout mice were protected from high-fat diet-induced obesity and exhibited an improvement of glucose tolerance and insulin sensitivity [137]. When FASN is acutely depleted in adipocytes using an inducible system, the mice displayed a significant increase in WAT browning even under a thermoneutrality condition [114]. The acute knockout of FASN in adipocytes also protected from high-fat diet-induced obesity and insulin resistance [114]. However, BAT-specific FASN deletion neither improved glucose tolerance nor induced iWAT browning [114,134], suggesting the beneficial effects of FASN deficiency in all adipocytes are only attributed to white adipocytes.

In terms of molecular mechanisms, two distinct models are proposed. In the first model, FASN is required to produce endogenous PPAR $\gamma$ ligands in a cell-autonomous fashion [137]. Fatty acids synthesized by FASN serve as the substrates of PexRAP, which generates alkyl ether lipids as PPAR $\gamma$ ligands [137]. Thus, loss of FASN decreases these ether lipids, altering the coactivator milieu to favor PPAR $\alpha$-dependent gene expression [137]. As a result, fatty acid oxidation and iWAT browning are increased, and diet-induced adiposity and insulin resistance are attenuated [137]. By contrast, in the second model, adipocyte FASN regulates the crosstalk between adipocytes and neurons $[114,134]$. In this model, FASN deficiency in adipocytes initiates neuronal signaling that triggers sympathetic stimulation to iWAT, which then activates the cAMP pathway and subsequently induces iWAT browning (Figure 2) [114,134].

Despite the disparity surrounding the molecular mechanisms, both studies show that loss of FASN indeed improves glucose metabolism and insulin sensitivity. This observation appears paradoxical to other studies showing that adipocyte DNL is beneficial to systemic glucose homeostasis and insulin sensitivity. One possible explanation is that depletion of FASN in adipocytes does not exactly mimic the decreased DNL that occurs in obesity, because other enzymes in the lipogenic pathway are also downregulated in obesity [114]

Therefore, the beneficial effects caused by the loss of FASN in adipocytes is more likely a pathophysiological compensation, instead of a physiological regulation. To better understand the role of DNL in WAT browning, adipocyte-specific ChREBP knockout mouse models may be useful in future studies.

\section{Conclusions and Perspectives}

DNL is an intrinsic metabolic process that converts excessive sugar to fat. Under normal physiological conditions, DNL in hepatocytes and adipocytes is synergistically regulated by signals from the peripheral tissues and the central nerve system. However, under pathophysiological conditions such as obesity, insulin resistance, and T2DM, the equilibration between hepatocyte and adipocyte DNL is disturbed, leading to increased DNL in the liver and decreased DNL in adipose tissues, which contributes to fatty liver and other relevant metabolic diseases.

Hepatocyte and adipocyte DNL are differentially regulated at the transcription level. SREBP-1c is a major lipogenic transcription factor in the liver, but plays a minor role in adipocyte DNL. LXRs stimulate DNL in the liver, but have almost opposite roles in adipose tissues. By contrast, ChREBPs are major lipogenic transcription factors in both hepatocytes and adipocytes. Importantly, the ChREBP levels in adipose tissues are highly correlated with insulin sensitivity in humans, and are reduced by high-fat diets or in obesity. Meanwhile, ChREBP-mediated DNL in adipocytes has beneficial 
effects on metabolism by generating insulin-sensitizing fatty acids such as FAHFAs. Therefore, ChREBP-mediated DNL is a potential drug target for the treatment of insulin resistance. To this end, two potential strategies may be adopted in the future. First, specific ChREBP agonists can be developed by targeting the glucose inhibitory domain or other activating steps of ChREBP- $\alpha$. Second, additional beneficial products of ChREBP-mediated DNL may be identified to serve as the drug leads.

Although recent studies have provided more insights into the regulation of adipocyte DNL and its physiological relevance, there are still important questions to be addressed. Most importantly, how is DNL in adipocytes regulated differently from that in hepatocytes? The answer to this question will help us to specifically activate DNL in adipocytes. In addition, what is the physiological role of DNL in brown and beige adipocytes? Future studies on adipocyte DNL will further improve our understanding on the role of lipid metabolism in insulin resistance.

Author Contributions: Z.S. wrote, and A.M.X. and F.Y. edited the manuscript.

Funding: This work was supported by grants from the National Institutes of Health (P30 DK041296 and DK020541, and R01 DK110063 and DK098439).

Acknowledgments: We wish to thank Qionghua Gao and Julie A. Yang for their helpful suggestions and comments to the manuscript. We apologize for being unable to cite all original studies due to the space limitation.

Conflicts of Interest: The authors declare no conflicts of interest with the contents of this article.

\section{Abbreviations}

\begin{tabular}{ll} 
DNL & de novo lipogenesis \\
AT & adipose tissue \\
WAT & white adipose tissue \\
TG & Triglyceride \\
FAHFA & fatty acid ester of hydroxyl fatty acid \\
PAHSA & palmitic acid ester of hydroxyl stearic acid \\
T2DM & type 2 diabetes \\
CVD & cardiovascular disease \\
NAFLD & non-alcoholic fatty liver disease \\
VLDL & very low density lipoproteins \\
NEFA & non-esterified fatty acids \\
LPL & lipoprotein lipase \\
FATP1 & fatty acid transport protein-1 \\
ATGL & adipose triglyceride lipase \\
DAG & diacylglycerol \\
HSL & hormone-sensitive lipase \\
MAG & monoacylglycerol \\
MGL & monoacylglycerol lipase \\
BAT & brown adipose tissue \\
TCA & tricarboxylic acid \\
ACLY & ATP-citrate lyase \\
ACC1 & acetyl-CoA carboxylase-1 \\
FASN & fatty acid synthase \\
SREBP & sterol regulatory element-binding protein \\
ChREBP & carbohydrate response element-binding protein \\
LXR & liver X receptor \\
ER & endoplasmic reticulum \\
SCAP & SREBP cleavage-activating protein \\
mTORC & mammalian target of rapamycin complex \\
SCD1 & stearoyl-CoA desaturase-1 \\
PPAR & peroxisome proliferator-activated receptor \\
BCKDH & branched-chain $\alpha$-ketoacid dehydrogenase \\
BCAA & branched-chain amino acids \\
\hline
\end{tabular}




$\begin{array}{ll}\text { AMPK } & \text { AMP-activated protein kinase } \\ \text { O-GlcNAc } & \text { O-Linked N-Acetylglucosamine } \\ \text { OGT } & \text { O-Linked N-Acetylglucosamine transferase } \\ \text { OGA } & \text { O-GlcNAcase } \\ \text { USP2A } & \text { ubiquitin-specific protease-2a } \\ \text { MBH } & \text { media basal hypothalamus } \\ \text { NPGL } & \text { neurosecretory protein GL } \\ \text { GPR120 } & \text { G protein-coupled receptor 120 }\end{array}$

\section{References}

1. Rosen, E.D.; Spiegelman, B.M. Adipocytes as regulators of energy balance and glucose homeostasis. Nature 2006, 444, 847-853. [CrossRef] [PubMed]

2. Booth, A.; Magnuson, A.; Fouts, J.; Foster, M.T. Adipose tissue: An endocrine organ playing a role in metabolic regulation. Horm. Mol. Biol. Clin. Investig. 2016, 26, 25-42. [CrossRef] [PubMed]

3. McGown, C.; Birerdinc, A.; Younossi, Z.M. Adipose tissue as an endocrine organ. Clin. Liver Dis. 2014, 18, 41-58. [CrossRef] [PubMed]

4. Frasca, D.; Diaz, A.; Romero, M.; Thaller, S.; Blomberg, B.B. Secretion of autoimmune antibodies in the human subcutaneous adipose tissue. PLoS ONE 2018, 13, e0197472. [CrossRef] [PubMed]

5. Yilmaz, M.; Claiborn, K.C.; Hotamisligil, G.S. De novo lipogenesis products and endogenous lipokines. Diabetes 2016, 65, 1800-1807. [CrossRef] [PubMed]

6. Moreno-Indias, I.; Tinahones, F.J. Impaired adipose tissue expandability and lipogenic capacities as ones of the main causes of metabolic disorders. J. Diabetes Res. 2015, 2015, 970375. [CrossRef] [PubMed]

7. Bluher, M. Adipose tissue dysfunction contributes to obesity related metabolic diseases. Best Pract. Res. Clin. Endocrinol. Metab. 2013, 27, 163-177. [CrossRef] [PubMed]

8. Rezaee, F.; Dashty, M. Role of adipose tissue in metabolic system disorders adipose tissue is the initiator of metabolic diseases. J. Diabetes Metab. 2013, S13. [CrossRef]

9. Guilherme, A.; Virbasius, J.V.; Puri, V.; Czech, M.P. Adipocyte dysfunctions linking obesity to insulin resistance and type 2 diabetes. Nat. Rev. Mol. Cell Biol. 2008, 9, 367-377. [CrossRef] [PubMed]

10. Erion, D.M.; Park, H.J.; Lee, H.Y. The role of lipids in the pathogenesis and treatment of type 2 diabetes and associated co-morbidities. BMB Rep. 2016, 49, 139-148. [CrossRef] [PubMed]

11. Mashima, T.; Seimiya, H.; Tsuruo, T. De novo fatty-acid synthesis and related pathways as molecular targets for cancer therapy. Br. J. Cancer 2009, 100, 1369-1372. [CrossRef] [PubMed]

12. Wong, R.H.; Sul, H.S. Insulin signaling in fatty acid and fat synthesis: A transcriptional perspective. Curr. Opin. Pharmacol. 2010, 10, 684-691. [CrossRef] [PubMed]

13. Merkel, M.; Eckel, R.H.; Goldberg, I.J. Lipoprotein lipase: Genetics, lipid uptake, and regulation. J. Lipid Res. 2002, 43, 1997-2006. [CrossRef] [PubMed]

14. Endemann, G.; Stanton, L.W.; Madden, K.S.; Bryant, C.M.; White, R.T.; Protter, A.A. Cd36 is a receptor for oxidized low density lipoprotein. J. Biol. Chem. 1993, 268, 11811-11816. [PubMed]

15. Wu, Q.; Ortegon, A.M.; Tsang, B.; Doege, H.; Feingold, K.R.; Stahl, A. Fatp1 is an insulin-sensitive fatty acid transporter involved in diet-induced obesity. Mol. Cell. Biol. 2006, 26, 3455-3467. [CrossRef] [PubMed]

16. Bolsoni-Lopes, A.; Alonso-Vale, M.I. Lipolysis and lipases in white adipose tissue-An update. Arch. Endocrinol. Metab 2015, 59, 335-342. [CrossRef] [PubMed]

17. Saponaro, C.; Gaggini, M.; Carli, F.; Gastaldelli, A. The subtle balance between lipolysis and lipogenesis: A critical point in metabolic homeostasis. Nutrients 2015, 7, 9453-9474. [CrossRef] [PubMed]

18. Kim, J.Y.; Nasr, A.; Tfayli, H.; Bacha, F.; Michaliszyn, S.F.; Arslanian, S. Increased lipolysis, diminished adipose tissue insulin sensitivity and impaired $\beta$-cell function relative to adipose tissue insulin sensitivity in obese youth with impaired glucose tolerance (IGT). Diabetes 2017, 66, 3085-3090. [CrossRef] [PubMed]

19. Vijayakumar, A.; Aryal, P.; Wen, J.; Syed, I.; Vazirani, R.P.; Moraes-Vieira, P.M.; Camporez, J.P.; Gallop, M.R.; Perry, R.J.; Peroni, O.D.; et al. Absence of carbohydrate response element binding protein in adipocytes causes systemic insulin resistance and impairs glucose transport. Cell Rep. 2017, 21, 1021-1035. [CrossRef] [PubMed] 
20. Morigny, P.; Houssier, M.; Mouisel, E.; Langin, D. Adipocyte lipolysis and insulin resistance. Biochimie 2016, 125, 259-266. [CrossRef] [PubMed]

21. Nielsen, T.S.; Jessen, N.; Jorgensen, J.O.; Moller, N.; Lund, S. Dissecting adipose tissue lipolysis: Molecular regulation and implications for metabolic disease. J. Mol. Endocrinol. 2014, 52, R199-R222. [CrossRef] [PubMed]

22. Fruhbeck, G.; Mendez-Gimenez, L.; Fernandez-Formoso, J.A.; Fernandez, S.; Rodriguez, A. Regulation of adipocyte lipolysis. Nutr. Res. Rev. 2014, 27, 63-93. [CrossRef] [PubMed]

23. Ameer, F.; Scandiuzzi, L.; Hasnain, S.; Kalbacher, H.; Zaidi, N. De novo lipogenesis in health and disease. Metabolism 2014, 63, 895-902. [CrossRef] [PubMed]

24. Solinas, G.; Boren, J.; Dulloo, A.G. De novo lipogenesis in metabolic homeostasis: More friend than foe? Mol. Metab. 2015, 4, 367-377. [CrossRef] [PubMed]

25. Hollands, M.A.; Cawthorne, M.A. Important sites of lipogenesis in the mouse other than liver and white adipose tissue. Biochem. J. 1981, 196, 645-647. [CrossRef] [PubMed]

26. Aarsland, A.; Chinkes, D.; Wolfe, R.R. Hepatic and whole-body fat synthesis in humans during carbohydrate overfeeding. Am. J. Clin. Nutr. 1997, 65, 1774-1782. [CrossRef] [PubMed]

27. Lodhi, I.J.; Wei, X.; Semenkovich, C.F. Lipoexpediency: De novo lipogenesis as a metabolic signal transmitter. Trends Endocrinol. Metab. 2011, 22, 1-8. [CrossRef] [PubMed]

28. Smith, U.; Kahn, B.B. Adipose tissue regulates insulin sensitivity: Role of adipogenesis, de novo lipogenesis and novel lipids. J. Intern. Med. 2016, 280, 465-475. [CrossRef] [PubMed]

29. Funai, K.; Song, H.; Yin, L.; Lodhi, I.J.; Wei, X.; Yoshino, J.; Coleman, T.; Semenkovich, C.F. Muscle lipogenesis balances insulin sensitivity and strength through calcium signaling. J. Clin. Investig. 2013, 123, 1229-1240. [CrossRef] [PubMed]

30. Tumanov, S.; Bulusu, V.; Kamphorst, J.J. Analysis of fatty acid metabolism using stable isotope tracers and mass spectrometry. Methods Enzymol. 2015, 561, 197-217. [PubMed]

31. Herath, K.B.; Zhong, W.; Yang, J.; Mahsut, A.; Rohm, R.J.; Shah, V.; Castro-Perez, J.; Zhou, H.; Attygalle, A.B.; Kang, L.; et al. Determination of low levels of $2 \mathrm{~h}$-labeling using high-resolution mass spectrometry: Application in studies of lipid flux and beyond. Rapid Commun. Mass Spectrom. 2014, 28, 239-244. [CrossRef] [PubMed]

32. Li, Y.; Xu, S.; Mihaylova, M.M.; Zheng, B.; Hou, X.; Jiang, B.; Park, O.; Luo, Z.; Lefai, E.; Shyy, J.Y.; et al. Ampk phosphorylates and inhibits srebp activity to attenuate hepatic steatosis and atherosclerosis in diet-induced insulin-resistant mice. Cell Metab. 2011, 13, 376-388. [CrossRef] [PubMed]

33. Kawaguchi, T.; Osatomi, K.; Yamashita, H.; Kabashima, T.; Uyeda, K. Mechanism for fatty acid "sparing" effect on glucose-induced transcription: Regulation of carbohydrate-responsive element-binding protein by amp-activated protein kinase. J. Biol. Chem. 2002, 277, 3829-3835. [CrossRef] [PubMed]

34. Lu, M.; Shyy, J.Y. Sterol regulatory element-binding protein 1 is negatively modulated by pka phosphorylation. Am. J. Physiol. Cell Physiol. 2006, 290, C1477-C1486. [CrossRef] [PubMed]

35. Kawaguchi, T.; Takenoshita, M.; Kabashima, T.; Uyeda, K. Glucose and camp regulate the l-type pyruvate kinase gene by phosphorylation/dephosphorylation of the carbohydrate response element binding protein. Proc. Natl. Acad. Sci. USA 2001, 98, 13710-13715. [CrossRef] [PubMed]

36. Sanchez-Gurmaches, J.; Tang, Y.; Jespersen, N.Z.; Wallace, M.; Martinez Calejman, C.; Gujja, S.; Li, H.; Edwards, Y.J.K.; Wolfrum, C.; Metallo, C.M.; et al. Brown fat akt2 is a cold-induced kinase that stimulates chrebp-mediated de novo lipogenesis to optimize fuel storage and thermogenesis. Cell Metab. 2018, 27, 195-209.e6. [CrossRef] [PubMed]

37. Tang, Y.; Wallace, M.; Sanchez-Gurmaches, J.; Hsiao, W.Y.; Li, H.; Lee, P.L.; Vernia, S.; Metallo, C.M.; Guertin, D.A. Adipose tissue mtorc2 regulates chrebp-driven de novo lipogenesis and hepatic glucose metabolism. Nat. Commun. 2016, 7, 11365. [CrossRef] [PubMed]

38. Sanders, F.W.; Griffin, J.L. De novo lipogenesis in the liver in health and disease: More than just a shunting yard for glucose. Biol. Rev. Camb. Philos. Soc. 2016, 91, 452-468. [CrossRef] [PubMed]

39. Menendez, J.A.; Vazquez-Martin, A.; Ortega, F.J.; Fernandez-Real, J.M. Fatty acid synthase: Association with insulin resistance, type 2 diabetes, and cancer. Clin. Chem. 2009, 55, 425-438. [CrossRef] [PubMed]

40. Eberle, D.; Hegarty, B.; Bossard, P.; Ferré, P.; Foufelle, F. Srebp transcription factors: Master regulators of lipid homeostasis. Biochimie 2004, 86, 839-848. [CrossRef] [PubMed] 
41. Shimano, H.; Horton, J.D.; Shimomura, I.; Hammer, R.E.; Brown, M.S.; Goldstein, J.L. Isoform 1c of sterol regulatory element binding protein is less active than isoform 1a in livers of transgenic mice and in cultured cells. J. Clin. Investig. 1997, 99, 846-854. [CrossRef] [PubMed]

42. Hua, X.; Wu, J.; Goldstein, J.L.; Brown, M.S.; Hobbs, H.H. Structure of the human gene encoding sterol regulatory element binding protein-1 (srebf1) and localization of srebf1 and srebf2 to chromosomes $17 \mathrm{p} 11.2$ and 22q13. Genomics 1995, 25, 667-673. [CrossRef]

43. Czech, M.P.; Tencerova, M.; Pedersen, D.J.; Aouadi, M. Insulin signalling mechanisms for triacylglycerol storage. Diabetologia 2013, 56, 949-964. [CrossRef] [PubMed]

44. Osborne, T.F. Sterol regulatory element-binding proteins (srebps): Key regulators of nutritional homeostasis and insulin action. J. Biol. Chem. 2000, 275, 32379-32382. [CrossRef] [PubMed]

45. Yellaturu, C.R.; Deng, X.; Cagen, L.M.; Wilcox, H.G.; Mansbach, C.M., 2nd; Siddiqi, S.A.; Park, E.A.; Raghow, R.; Elam, M.B. Insulin enhances post-translational processing of nascent srebp-1c by promoting its phosphorylation and association with copii vesicles. J. Biol. Chem. 2009, 284, 7518-7532. [CrossRef] [PubMed]

46. Schultz, J.R.; Tu, H.; Luk, A.; Repa, J.J.; Medina, J.C.; Li, L.; Schwendner, S.; Wang, S.; Thoolen, M.; Mangelsdorf, D.J.; et al. Role of lxrs in control of lipogenesis. Genes Dev. 2000, 14, 2831-2838. [CrossRef] [PubMed]

47. Repa, J.J.; Liang, G.; Ou, J.; Bashmakov, Y.; Lobaccaro, J.M.; Shimomura, I.; Shan, B.; Brown, M.S.; Goldstein, J.L.; Mangelsdorf, D.J. Regulation of mouse sterol regulatory element-binding protein-1c gene (srebp-1c) by oxysterol receptors, lxralpha and lxrbeta. Genes Dev. 2000, 14, 2819-2830. [CrossRef] [PubMed]

48. Goldstein, J.L.; DeBose-Boyd, R.A.; Brown, M.S. Protein sensors for membrane sterols. Cell 2006, 124, 35-46. [CrossRef] [PubMed]

49. Bakan, I.; Laplante, M. Connecting mtorc1 signaling to srebp-1 activation. Curr. Opin. Lipidol. 2012, 23, 226-234. [CrossRef] [PubMed]

50. Wu, X.; Romero, D.; Swiatek, W.I.; Dorweiler, I.; Kikani, C.K.; Sabic, H.; Zweifel, B.S.; McKearn, J.; Blitzer, J.T.; Nickols, G.A.; et al. Pas kinase drives lipogenesis through srebp-1 maturation. Cell Rep. 2014, 8, 242-255. [CrossRef] [PubMed]

51. Sundqvist, A.; Bengoechea-Alonso, M.T.; Ye, X.; Lukiyanchuk, V.; Jin, J.; Harper, J.W.; Ericsson, J. Control of lipid metabolism by phosphorylation-dependent degradation of the srebp family of transcription factors by scf(fbw7). Cell Metab. 2005, 1, 379-391. [CrossRef] [PubMed]

52. Peterson, T.R.; Sengupta, S.S.; Harris, T.E.; Carmack, A.E.; Kang, S.A.; Balderas, E.; Guertin, D.A.; Madden, K.L.; Carpenter, A.E.; Finck, B.N. Mtor complex 1 regulates lipin 1 localization to control the srebp pathway. Cell 2011, 146, 408-420. [CrossRef] [PubMed]

53. Zhao, X.; Feng, D.; Wang, Q.; Abdulla, A.; Xie, X.J.; Zhou, J.; Sun, Y.; Yang, E.S.; Liu, L.P.; Vaitheesvaran, B.; et al. Regulation of lipogenesis by cyclin-dependent kinase 8-mediated control of srebp-1. J. Clin. Investig. 2012, 122, 2417-2427. [CrossRef] [PubMed]

54. Kohjima, M.; Higuchi, N.; Kato, M.; Kotoh, K.; Yoshimoto, T.; Fujino, T.; Yada, M.; Yada, R.; Harada, N.; Enjoji, M.; et al. Srebp-1c, regulated by the insulin and ampk signaling pathways, plays a role in nonalcoholic fatty liver disease. Int. J. Mol. Med. 2008, 21, 507-511. [CrossRef] [PubMed]

55. Shimomura, I.; Bashmakov, Y.; Horton, J.D. Increased levels of nuclear srebp-1c associated with fatty livers in two mouse models of diabetes mellitus. J. Biol. Chem. 1999, 274, 30028-30032. [CrossRef] [PubMed]

56. Knebel, B.; Haas, J.; Hartwig, S.; Jacob, S.; Köllmer, C.; Nitzgen, U.; Muller-Wieland, D.; Kotzka, J. Liver-specific expression of transcriptionally active srebp-1c is associated with fatty liver and increased visceral fat mass. PLoS ONE 2012, 7, e31812. [CrossRef] [PubMed]

57. Yahagi, N.; Shimano, H.; Hasty, A.H.; Matsuzaka, T.; Ide, T.; Yoshikawa, T.; Amemiya-Kudo, M.; Tomita, S.; Okazaki, H.; Tamura, Y.; et al. Absence of sterol regulatory element-binding protein-1 (srebp-1) ameliorates fatty livers but not obesity or insulin resistance in lep(ob)/lep(ob) mice. J. Biol. Chem. 2002, 277, 19353-19357. [CrossRef] [PubMed]

58. Moon, Y.A.; Liang, G.; Xie, X.; Frank-Kamenetsky, M.; Fitzgerald, K.; Koteliansky, V.; Brown, M.S.; Goldstein, J.L.; Horton, J.D. The scap/srebp pathway is essential for developing diabetic fatty liver and carbohydrate-induced hypertriglyceridemia in animals. Cell Metab. 2012, 15, 240-246. [CrossRef] [PubMed]

59. Kim, J.B.; Spiegelman, B.M. Add1/srebp1 promotes adipocyte differentiation and gene expression linked to fatty acid metabolism. Genes Dev. 1996, 10, 1096-1107. [CrossRef] [PubMed] 
60. Shimano, H.; Shimomura, I.; Hammer, R.E.; Herz, J.; Goldstein, J.L.; Brown, M.S.; Horton, J.D. Elevated levels of srebp-2 and cholesterol synthesis in livers of mice homozygous for a targeted disruption of the srebp-1 gene. J. Clin. Investig. 1997, 100, 2115-2124. [CrossRef] [PubMed]

61. Fujii, N.; Narita, T.; Okita, N.; Kobayashi, M.; Furuta, Y.; Chujo, Y.; Sakai, M.; Yamada, A.; Takeda, K.; Konishi, T. Sterol regulatory element-binding protein-1c orchestrates metabolic remodeling of white adipose tissue by caloric restriction. Aging Cell 2017, 16, 508-517. [CrossRef] [PubMed]

62. Sekiya, M.; Yahagi, N.; Matsuzaka, T.; Takeuchi, Y.; Nakagawa, Y.; Takahashi, H.; Okazaki, H.; Iizuka, Y.; Ohashi, K.; Gotoda, T.; et al. Srebp-1-independent regulation of lipogenic gene expression in adipocytes. J. Lipid Res. 2007, 48, 1581-1591. [CrossRef] [PubMed]

63. Horton, J.D.; Shimomura, I.; Ikemoto, S.; Bashmakov, Y.; Hammer, R.E. Overexpression of sterol regulatory element-binding protein-1a in mouse adipose tissue produces adipocyte hypertrophy, increased fatty acid secretion, and fatty liver. J. Biol. Chem. 2003, 278, 36652-36660. [CrossRef] [PubMed]

64. Shimomura, I.; Hammer, R.E.; Richardson, J.A.; Ikemoto, S.; Bashmakov, Y.; Goldstein, J.L.; Brown, M.S. Insulin resistance and diabetes mellitus in transgenic mice expressing nuclear srebp-1c in adipose tissue: Model for congenital generalized lipodystrophy. Genes Dev. 1998, 12, 3182-3194. [CrossRef] [PubMed]

65. Makowski, L.; Boord, J.B.; Maeda, K.; Babaev, V.R.; Uysal, K.T.; Morgan, M.A.; Parker, R.A.; Suttles, J.; Fazio, S.; Hotamisligil, G.S.; et al. Lack of macrophage fatty-acid-binding protein ap2 protects mice deficient in apolipoprotein e against atherosclerosis. Nat. Med. 2001, 7, 699-705. [CrossRef] [PubMed]

66. Biswas, S.K.; Mantovani, A. Orchestration of metabolism by macrophages. Cell Metab. 2012, 15, $432-437$. [CrossRef] [PubMed]

67. Villarroya, F.; Cereijo, R.; Villarroya, J.; Gavalda-Navarro, A.; Giralt, M. Toward an understanding of how immune cells control brown and beige adipobiology. Cell Metab. 2018, 27, 954-961. [CrossRef] [PubMed]

68. Iizuka, K.; Bruick, R.K.; Liang, G.; Horton, J.D.; Uyeda, K. Deficiency of carbohydrate response element-binding protein (chrebp) reduces lipogenesis as well as glycolysis. Proc. Natl. Acad. Sci. USA 2004, 101, 7281-7286. [CrossRef] [PubMed]

69. Uyeda, K.; Yamashita, H.; Kawaguchi, T. Carbohydrate responsive element-binding protein (chrebp): A key regulator of glucose metabolism and fat storage. Biochem. Pharmacol. 2002, 63, 2075-2080. [CrossRef]

70. Herman, M.A.; Peroni, O.D.; Villoria, J.; Schon, M.R.; Abumrad, N.A.; Bluher, M.; Klein, S.; Kahn, B.B. A novel chrebp isoform in adipose tissue regulates systemic glucose metabolism. Nature 2012, 484, 333-338. [CrossRef] [PubMed]

71. Li, M.V.; Chen, W.; Harmancey, R.N.; Nuotio-Antar, A.M.; Imamura, M.; Saha, P.; Taegtmeyer, H.; Chan, L. Glucose-6-phosphate mediates activation of the carbohydrate responsive binding protein (chrebp). Biochem. Biophys. Res. Commun. 2010, 395, 395-400. [CrossRef] [PubMed]

72. Kabashima, T.; Kawaguchi, T.; Wadzinski, B.E.; Uyeda, K. Xylulose 5-phosphate mediates glucose-induced lipogenesis by xylulose 5-phosphate-activated protein phosphatase in rat liver. Proc. Natl. Acad. Sci. USA 2003, 100, 5107-5112. [CrossRef] [PubMed]

73. Sato, S.; Jung, H.; Nakagawa, T.; Pawlosky, R.; Takeshima, T.; Lee, W.R.; Sakiyama, H.; Laxman, S.; Wynn, R.M.; Tu, B.P.; et al. Metabolite regulation of nuclear localization of carbohydrate-response element-binding protein (chrebp): Role of amp as an allosteric inhibitor. J. Biol. Chem. 2016, 291, 10515-10527. [CrossRef] [PubMed]

74. Stoeckman, A.K.; Ma, L.; Towle, H.C. Mlx is the functional heteromeric partner of the carbohydrate response element-binding protein in glucose regulation of lipogenic enzyme genes. J. Biol. Chem. 2004, 279, 15662-15669. [CrossRef] [PubMed]

75. Denechaud, P.D.; Dentin, R.; Girard, J.; Postic, C. Role of chrebp in hepatic steatosis and insulin resistance. FEBS Lett. 2008, 582, 68-73. [CrossRef] [PubMed]

76. Hurtado del Pozo, C.; Vesperinas-Garcia, G.; Rubio, M.A.; Corripio-Sanchez, R.; Torres-Garcia, A.J.; Obregon, M.J.; Calvo, R.M. Chrebp expression in the liver, adipose tissue and differentiated preadipocytes in human obesity. Biochim. Biophys. Acta 2011, 1811, 1194-1200. [CrossRef] [PubMed]

77. Witte, N.; Muenzner, M.; Rietscher, J.; Knauer, M.; Heidenreich, S.; Nuotio-Antar, A.M.; Graef, F.A.; Fedders, R.; Tolkachov, A.; Goehring, I.; et al. The glucose sensor chrebp links de novo lipogenesis to ppargamma activity and adipocyte differentiation. Endocrinology 2015, 156, 4008-4019. [CrossRef] [PubMed] 
78. Nuotio-Antar, A.M.; Poungvarin, N.; Li, M.; Schupp, M.; Mohammad, M.; Gerard, S.; Zou, F.; Chan, L. Fabp4-cre mediated expression of constitutively active chrebp protects against obesity, fatty liver, and insulin resistance. Endocrinology 2015, 156, 4020-4032. [CrossRef] [PubMed]

79. Hung, C.M.; Calejman, C.M.; Sanchez-Gurmaches, J.; Li, H.; Clish, C.B.; Hettmer, S.; Wagers, A.J.; Guertin, D.A. Rictor/mtorc2 loss in the myf5 lineage reprograms brown fat metabolism and protects mice against obesity and metabolic disease. Cell Rep. 2014, 8, 256-271. [CrossRef] [PubMed]

80. Bartelt, A.; Weigelt, C.; Cherradi, M.L.; Niemeier, A.; Todter, K.; Heeren, J.; Scheja, L. Effects of adipocyte lipoprotein lipase on de novo lipogenesis and white adipose tissue browning. Biochim. Biophys. Acta 2013, 1831, 934-942. [CrossRef] [PubMed]

81. Peet, D.J.; Turley, S.D.; Ma, W.; Janowski, B.A.; Lobaccaro, J.-M.A.; Hammer, R.E.; Mangelsdorf, D.J. Cholesterol and bile acid metabolism are impaired in mice lacking the nuclear oxysterol receptor lxr $\alpha$. Cell 1998, 93, 693-704. [CrossRef]

82. Alberti, S.; Steffensen, K.R.; Gustafsson, J.-Å. Structural characterisation of the mouse nuclear oxysterol receptor genes $1 x r \alpha$ and $\operatorname{lxr} \beta$. Gene 2000, 243, 93-103. [CrossRef]

83. Willy, P.J.; Umesono, K.; Ong, E.S.; Evans, R.M.; Heyman, R.A.; Mangelsdorf, D.J. Lxr, a nuclear receptor that defines a distinct retinoid response pathway. Genes Dev. 1995, 9, 1033-1045. [CrossRef] [PubMed]

84. Song, C.; Kokontis, J.M.; Hiipakka, R.A.; Liao, S. Ubiquitous receptor: A receptor that modulates gene activation by retinoic acid and thyroid hormone receptors. Proc. Natl. Acad. Sci. USA 1994, 91, 10809-10813. [CrossRef] [PubMed]

85. Jakobsson, T.; Treuter, E.; Gustafsson, J.A.; Steffensen, K.R. Liver x receptor biology and pharmacology: New pathways, challenges and opportunities. Trends Pharmacol. Sci. 2012, 33, 394-404. [CrossRef] [PubMed]

86. Yamamoto, T.; Shimano, H.; Inoue, N.; Nakagawa, Y.; Matsuzaka, T.; Takahashi, A.; Yahagi, N.; Sone, H.; Suzuki, H.; Toyoshima, H.; et al. Protein kinase a suppresses sterol regulatory element-binding protein-1c expression via phosphorylation of liver $x$ receptor in the liver. J. Biol. Chem. 2007, 282, 11687-11695. [CrossRef] [PubMed]

87. Dong, Y.; Xu, Z.; Zhang, Z.; Yin, X.; Lin, X.; Li, H.; Zheng, F. Impaired adipose expansion caused by liver $x$ receptor activation is associated with insulin resistance in mice fed a high-fat diet. J. Mol. Endocrinol. 2017, 58, 141-154. [CrossRef] [PubMed]

88. Beaven, S.W.; Matveyenko, A.; Wroblewski, K.; Chao, L.; Wilpitz, D.; Hsu, T.W.; Lentz, J.; Drew, B.; Hevener, A.L.; Tontonoz, P. Reciprocal regulation of hepatic and adipose lipogenesis by liver $\mathrm{x}$ receptors in obesity and insulin resistance. Cell Metab. 2013, 18, 106-117. [CrossRef] [PubMed]

89. Jois, T.; Chen, W.; Howard, V.; Harvey, R.; Youngs, K.; Thalmann, C.; Saha, P.; Chan, L.; Cowley, M.A.; Sleeman, M.W. Deletion of hepatic carbohydrate response element binding protein (chrebp) impairs glucose homeostasis and hepatic insulin sensitivity in mice. Mol. Metab. 2017, 6, 1381-1394. [CrossRef] [PubMed]

90. Dib, L.; Bugge, A.; Collins, S. Lxralpha fuels fatty acid-stimulated oxygen consumption in white adipocytes. J. Lipid Res. 2014, 55, 247-257. [CrossRef] [PubMed]

91. Shimano, H.; Horton, J.D.; Hammer, R.E.; Shimomura, I.; Brown, M.S.; Goldstein, J.L. Overproduction of cholesterol and fatty acids causes massive liver enlargement in transgenic mice expressing truncated srebp-1a. J. Clin. Investig. 1996, 98, 1575-1584. [CrossRef] [PubMed]

92. Benhamed, F.; Denechaud, P.D.; Lemoine, M.; Robichon, C.; Moldes, M.; Bertrand-Michel, J.; Ratziu, V.; Serfaty, L.; Housset, C.; Capeau, J.; et al. The lipogenic transcription factor chrebp dissociates hepatic steatosis from insulin resistance in mice and humans. J. Clin. Investig. 2012, 122, 2176-2194. [CrossRef] [PubMed]

93. White, P.J.; McGarrah, R.W.; Grimsrud, P.A.; Tso, S.C.; Yang, W.H.; Haldeman, J.M.; Grenier-Larouche, T.; An, J.; Lapworth, A.L.; Astapova, I.; et al. The bckdh kinase and phosphatase integrate bcaa and lipid metabolism via regulation of atp-citrate lyase. Cell Metab. 2018, 27, 1281-1293. [CrossRef] [PubMed]

94. Daval, M.; Foufelle, F.; Ferre, P. Functions of amp-activated protein kinase in adipose tissue. J. Physiol. 2006, 574, 55-62. [CrossRef] [PubMed]

95. Galic, S.; Loh, K.; Murray-Segal, L.; Steinberg, G.R.; Andrews, Z.B.; Kemp, B.E. Ampk signaling to acetyl-coa carboxylase is required for fasting-and cold-induced appetite but not thermogenesis. eLife 2018, 7, e32656. [CrossRef] [PubMed]

96. Hardie, D.G. Regulation of fatty acid synthesis via phosphorylation of acetyl-coa carboxylase. Prog. Lipid Res. 1989, 28, 117-146. [CrossRef] 
97. An, Z.; Wang, H.; Song, P.; Zhang, M.; Geng, X.; Zou, M.H. Nicotine-induced activation of amp-activated protein kinase inhibits fatty acid synthase in 3t311 adipocytes: A role for oxidant stress. J. Biol. Chem. 2007, 282, 26793-26801. [CrossRef] [PubMed]

98. Iyer, S.P.N.; Hart, G.W. O-glcnac transferase. In Handbook of Glycosyltransferases and Related Genes; Springer-Verlag: Tokyo, Japan, 2002; pp. 158-163.

99. Dong, D.L.; Hart, G.W. Purification and characterization of an o-glcnac selective n-acetyl-beta-d-glucosaminidase from rat spleen cytosol. J. Biol. Chem. 1994, 269, 19321-19330. [PubMed]

100. Baldini, S.F.; Wavelet, C.; Hainault, I.; Guinez, C.; Lefebvre, T. The nutrient-dependent o-glcnac modification controls the expression of liver fatty acid synthase. J. Mol. Biol. 2016, 428, 3295-3304. [CrossRef] [PubMed]

101. Graner, E.; Tang, D.; Rossi, S.; Baron, A.; Migita, T.; Weinstein, L.J.; Lechpammer, M.; Huesken, D.; Zimmermann, J.; Signoretti, S. The isopeptidase usp2a regulates the stability of fatty acid synthase in prostate cancer. Cancer Cell 2004, 5, 253-261. [CrossRef]

102. Teo, C.F.; Wollaston-Hayden, E.E.; Wells, L. Hexosamine flux, the o-glcnac modification, and the development of insulin resistance in adipocytes. Mol. Cell. Endocrinol. 2010, 318, 44-53. [CrossRef] [PubMed]

103. Vaidyanathan, K.; Wells, L. Multiple tissue-specific roles for the o-glcnac post-translational modification in the induction of and complications arising from type ii diabetes. J. Biol. Chem. 2014, 289, 34466-34471. [CrossRef] [PubMed]

104. Myers, M.G., Jr.; Olson, D.P. Central nervous system control of metabolism. Nature 2012, 491, $357-363$. [CrossRef] [PubMed]

105. Nogueiras, R.; Wiedmer, P.; Perez-Tilve, D.; Veyrat-Durebex, C.; Keogh, J.M.; Sutton, G.M.; Pfluger, P.T.; Castaneda, T.R.; Neschen, S.; Hofmann, S.M.; et al. The central melanocortin system directly controls peripheral lipid metabolism. J. Clin. Investig. 2007, 117, 3475-3488. [CrossRef] [PubMed]

106. Scherer, T.; Buettner, C. Yin and yang of hypothalamic insulin and leptin signaling in regulating white adipose tissue metabolism. Rev. Endocr. Metab. Disord. 2011, 12, 235-243. [CrossRef] [PubMed]

107. Scherer, T.; O’Hare, J.; Diggs-Andrews, K.; Schweiger, M.; Cheng, B.; Lindtner, C.; Zielinski, E.; Vempati, P.; $\mathrm{Su}, \mathrm{K}$; Dighe, S.; et al. Brain insulin controls adipose tissue lipolysis and lipogenesis. Cell Metab. 2011, 13, 183-194. [CrossRef] [PubMed]

108. Buettner, C.; Muse, E.D.; Cheng, A.; Chen, L.; Scherer, T.; Pocai, A.; Su, K.; Cheng, B.; Li, X.; Harvey-White, J.; et al. Leptin controls adipose tissue lipogenesis via central, stat3-independent mechanisms. Nat. Med. 2008, 14, 667-675. [CrossRef] [PubMed]

109. Osei-Hyiaman, D.; DePetrillo, M.; Pacher, P.; Liu, J.; Radaeva, S.; Batkai, S.; Harvey-White, J.; Mackie, K.; Offertaler, L.; Wang, L.; et al. Endocannabinoid activation at hepatic cb1 receptors stimulates fatty acid synthesis and contributes to diet-induced obesity. J. Clin. Investig. 2005, 115, 1298-1305. [CrossRef] [PubMed]

110. Iwakoshi-Ukena, E.; Shikano, K.; Kondo, K.; Taniuchi, S.; Furumitsu, M.; Ochi, Y.; Sasaki, T.; Okamoto, S.; Bentley, G.E.; Kriegsfeld, L.J. Neurosecretory protein gl stimulates food intake, de novo lipogenesis, and onset of obesity. eLife 2017, 6, e28527. [CrossRef] [PubMed]

111. Eissing, L.; Scherer, T.; Todter, K.; Knippschild, U.; Greve, J.W.; Buurman, W.A.; Pinnschmidt, H.O.; Rensen, S.S.; Wolf, A.M.; Bartelt, A.; et al. De novo lipogenesis in human fat and liver is linked to chrebp-beta and metabolic health. Nat. Commun. 2013, 4, 1528. [CrossRef] [PubMed]

112. Jia, G.; Whaley-Connell, A.; Sowers, J.R. Diabetic cardiomyopathy: A hyperglycaemia-and insulin-resistance-induced heart disease. Diabetologia 2018, 61, 21-28. [CrossRef] [PubMed]

113. Poungvarin, N.; Lee, J.; Yechoor, V.; Li, M.; Assavapokee, T.; Suksaranjit, P.; Thepsongwajja, J.; Saha, P.; Oka, K.; Chan, L. Carbohydrate response element-binding protein (chrebp) plays a pivotal role in beta cell glucotoxicity. Diabetologia 2012, 55, 1783-1796. [CrossRef] [PubMed]

114. Guilherme, A.; Pedersen, D.J.; Henchey, E.; Henriques, F.S.; Danai, L.V.; Shen, Y.; Yenilmez, B.; Jung, D.; Kim, J.K.; Lodhi, I.J.; et al. Adipocyte lipid synthesis coupled to neuronal control of thermogenic programming. Mol. Metab. 2017, 6, 781-796. [CrossRef] [PubMed]

115. Auguet, T.; Guiu-Jurado, E.; Berlanga, A.; Terra, X.; Martinez, S.; Porras, J.A.; Ceausu, A.; Sabench, F.; Hernandez, M.; Aguilar, C. Downregulation of lipogenesis and fatty acid oxidation in the subcutaneous adipose tissue of morbidly obese women. Obesity 2014, 22, 2032-2038. [CrossRef] [PubMed] 
116. Allister, C.A.; Liu, L.F.; Lamendola, C.A.; Craig, C.M.; Cushman, S.W.; Hellerstein, M.K.; McLaughlin, T.L. In vivo $2 \mathrm{~h} 2 \mathrm{o}$ administration reveals impaired triglyceride storage in adipose tissue of insulin-resistant humans. J. Lipid Res. 2015, 56, 435-439. [CrossRef] [PubMed]

117. Roberts, R.; Hodson, L.; Dennis, A.; Neville, M.; Humphreys, S.; Harnden, K.; Micklem, K.; Frayn, K. Markers of de novo lipogenesis in adipose tissue: Associations with small adipocytes and insulin sensitivity in humans. Diabetologia 2009, 52, 882-890. [CrossRef] [PubMed]

118. Cao, H.; Gerhold, K.; Mayers, J.R.; Wiest, M.M.; Watkins, S.M.; Hotamisligil, G.S. Identification of a lipokine, a lipid hormone linking adipose tissue to systemic metabolism. Cell 2008, 134, 933-944. [CrossRef] [PubMed]

119. Yore, M.M.; Syed, I.; Moraes-Vieira, P.M.; Zhang, T.; Herman, M.A.; Homan, E.A.; Patel, R.T.; Lee, J.; Chen, S.; Peroni, O.D. Discovery of a class of endogenous mammalian lipids with anti-diabetic and anti-inflammatory effects. Cell 2014, 159, 318-332. [CrossRef] [PubMed]

120. Ntambi, J.M.; Miyazaki, M. Regulation of stearoyl-coa desaturases and role in metabolism. Prog. Lipid Res. 2004, 43, 91-104. [CrossRef]

121. De Souza, C.O.; Vannice, G.K.; Rosa Neto, J.C.; Calder, P.C. Is palmitoleic acid a plausible nonpharmacological strategy to prevent or control chronic metabolic and inflammatory disorders? Mol. Nutr. Food Res. 2018, 62, 1700504. [CrossRef] [PubMed]

122. Frigolet, M.E.; Gutierrez-Aguilar, R. The role of the novel lipokine palmitoleic acid in health and disease. Adv. Nutr. 2017, 8, 173S-181S. [CrossRef] [PubMed]

123. Stefan, N.; Kantartzis, K.; Celebi, N.; Staiger, H.; Machann, J.; Schick, F.; Cegan, A.; Elcnerova, M.; Schleicher, E.; Fritsche, A.; et al. Circulating palmitoleate strongly and independently predicts insulin sensitivity in humans. Diabetes Care 2010, 33, 405-407. [CrossRef] [PubMed]

124. Fabbrini, E.; Magkos, F.; Su, X.; Abumrad, N.A.; Nejedly, N.; Coughlin, C.C.; Okunade, A.L.; Patterson, B.W.; Klein, S. Insulin sensitivity is not associated with palmitoleate availability in obese humans. J. Lipid Res. 2011, 52, 808-812. [CrossRef] [PubMed]

125. Bergman, B.C.; Howard, D.; Schauer, I.E.; Maahs, D.M.; Snell-Bergeon, J.K.; Clement, T.W.; Eckel, R.H.; Perreault, L.; Rewers, M. The importance of palmitoleic acid to adipocyte insulin resistance and whole-body insulin sensitivity in type 1 diabetes. J. Clin. Endocrinol. Metab. 2013, 98, E40-E50. [CrossRef] [PubMed]

126. Moraes-Vieira, P.M.; Saghatelian, A.; Kahn, B.B. Glut4 expression in adipocytes regulates de novo lipogenesis and levels of a novel class of lipids with antidiabetic and anti-inflammatory effects. Diabetes 2016, 65, 1808-1815. [CrossRef] [PubMed]

127. Stanford, K.I.; Lynes, M.D.; Takahashi, H.; Baer, L.A.; Arts, P.J.; May, F.J.; Lehnig, A.C.; Middelbeek, R.J.W.; Richard, J.J.; So, K.; et al. 12,13-dihome: An exercise-induced lipokine that increases skeletal muscle fatty acid uptake. Cell Metab. 2018, 27, 1111-1120.e3. [CrossRef] [PubMed]

128. Lynes, M.D.; Leiria, L.O.; Lundh, M.; Bartelt, A.; Shamsi, F.; Huang, T.L.; Takahashi, H.; Hirshman, M.F.; Schlein, C.; Lee, A.; et al. The cold-induced lipokine 12,13-dihome promotes fatty acid transport into brown adipose tissue. Nat. Med. 2017, 23, 631-637. [CrossRef] [PubMed]

129. Peirce, V.; Vidal-Puig, A. Regulation of glucose homoeostasis by brown adipose tissue. Lancet Diabetes Endocrinol. 2013, 1, 353-360. [CrossRef]

130. Harms, M.; Seale, P. Brown and beige fat: Development, function and therapeutic potential. Nat. Med. 2013, 19, 1252-1263. [CrossRef] [PubMed]

131. Wu, J.; Boström, P.; Sparks, L.M.; Ye, L.; Choi, J.H.; Giang, A.-H.; Khandekar, M.; Virtanen, K.A.; Nuutila, P.; Schaart, G. Beige adipocytes are a distinct type of thermogenic fat cell in mouse and human. Cell 2012, 150, 366-376. [CrossRef] [PubMed]

132. Van der Lans, A.A.; Hoeks, J.; Brans, B.; Vijgen, G.H.; Visser, M.G.; Vosselman, M.J.; Hansen, J.; Jorgensen, J.A.; $\mathrm{Wu}$, J.; Mottaghy, F.M.; et al. Cold acclimation recruits human brown fat and increases nonshivering thermogenesis. J. Clin. Investig. 2013, 123, 3395-3403. [CrossRef] [PubMed]

133. Kozak, L.P.; Koza, R.A.; Anunciado-Koza, R. Brown fat thermogenesis and body weight regulation in mice: Relevance to humans. Int. J. Obes. 2010, 34 (Suppl. 1), S23-S27. [CrossRef] [PubMed]

134. Guilherme, A.; Pedersen, D.J.; Henriques, F.; Bedard, A.H.; Henchey, E.; Kelly, M.; Morgan, D.A.; Rahmouni, K.; Czech, M.P. Neuronal modulation of brown adipose activity through perturbation of white adipocyte lipogenesis. Mol. Metab. 2018. [CrossRef] [PubMed] 
135. Schreiber, R.; Diwoky, C.; Schoiswohl, G.; Feiler, U.; Wongsiriroj, N.; Abdellatif, M.; Kolb, D.; Hoeks, J.; Kershaw, E.E.; Sedej, S.; et al. Cold-induced thermogenesis depends on atgl-mediated lipolysis in cardiac muscle, but not brown adipose tissue. Cell Metab. 2017, 26, 753-763.e7. [CrossRef] [PubMed]

136. Shin, H.; Ma, Y.; Chanturiya, T.; Cao, Q.; Wang, Y.; Kadegowda, A.K.G.; Jackson, R.; Rumore, D.; Xue, B.; Shi, H.; et al. Lipolysis in brown adipocytes is not essential for cold-induced thermogenesis in mice. Cell Metab. 2017, 26, 764-777. [CrossRef] [PubMed]

137. Lodhi, I.J.; Yin, L.; Jensen-Urstad, A.P.; Funai, K.; Coleman, T.; Baird, J.H.; El Ramahi, M.K.; Razani, B.; Song, H.; Fu-Hsu, F.; et al. Inhibiting adipose tissue lipogenesis reprograms thermogenesis and ppargamma activation to decrease diet-induced obesity. Cell Metab. 2012, 16, 189-201. [CrossRef] [PubMed]

(C) 2018 by the authors. Licensee MDPI, Basel, Switzerland. This article is an open access article distributed under the terms and conditions of the Creative Commons Attribution (CC BY) license (http://creativecommons.org/licenses/by/4.0/). 